\title{
Key factors affecting single scattering albedo calculation: Implications for aerosol climate forcing
}

Duseong S. Jo1, a, b, Rokjin J. Park ${ }^{1, ~}{ }^{*}$, Jaein I. Jeong ${ }^{1}$, Gabriele Curci², Hyung-Min Lee ${ }^{3, c}$,

5 and Sang-Woo Kim ${ }^{1}$

${ }^{1}$ School of Earth and Environmental Science, Seoul National University, Seoul, Republic of Korea

${ }^{2}$ Department of Physical and Chemical Sciences, Center of Excellence for the Forecast of

10 Severe Weather (CETEMPS), University of L'Aquila, L'Aquila, Italy

${ }^{3}$ Department of Civil, Environmental, and Architectural Engineering, University of Colorado, Boulder, CO, USA

anow at Cooperative Institute for Research in Environmental Sciences, University of Colorado, Boulder, CO, USA

15 bnow at Department of Chemistry and Biochemistry, University of Colorado, Boulder, CO, USA

${ }^{\mathrm{c}}$ now at School of Earth and Environmental Science, Seoul National University, Seoul, Republic of Korea

20

\footnotetext{
*Correspondence to: R. J. Park (rjpark@snu.ac.kr)
} 
Atmos. Chem. Phys. Discuss., https://doi.org/10.5194/acp-2017-1104

Manuscript under review for journal Atmos. Chem. Phys.

Discussion started: 4 December 2017

(c) Author(s) 2017. CC BY 4.0 License.

\section{Abstract}

Single Scattering Albedo (SSA), the ratio of scattering efficiency to total extinction efficiency, is an essential parameter used to estimate the Direct Radiative Forcing (DRF) of aerosols. However, SSA is one of the large contributors to the uncertainty of DRF estimations. In this study, we examined the sensitivity of SSA calculations to the physical properties of absorbing aerosols, in particular, Black Carbon (BC), Brown Carbon (BrC), and dust. We used GEOS-Chem 3-D global chemical transport model (CTM) simulations and a post-processing tool for the aerosol optical properties (FlexAOD). The model and input parameters were evaluated by comparison against the observed aerosol mass concentrations and the Aerosol Optical Depth (AOD) values obtained from global surface observation networks such as the global Aerosol Mass Spectrometer (AMS) dataset, the Surface Particulate Matter Network (SPARTAN), and the Aerosol Robotic Network (AERONET). The model was generally successful in reproducing the observed variability of both the Particulate Matter $2.5 \mu \mathrm{m}\left(\mathrm{PM}_{2.5}\right)$ and AOD $(\mathrm{R} \sim 0.76)$ values, although it underestimated the magnitudes by approximately $20 \%$. Our sensitivity tests of the SSA calculation revealed that the aerosol physical parameters, which have generally received less attention than the aerosol mass loadings, can cause large uncertainties in the resulting DRF estimation. For example, large variations in the calculated $\mathrm{BC}$ absorption may result from slight changes of the geometric mean radius, geometric standard deviation, real and imaginary refractive indices, and density. The inclusion of $\mathrm{BrC}$ and observationally-constrained dust size distributions also significantly affected the SSA, and resulted in a remarkable improvement for the simulated SSA at $440 \mathrm{~nm}$ (bias was reduced by $44-49 \%$ ) compared with the AERONET observations. Based on the simulations performed during this study, we found that the global aerosol direct radiative effect was increased by $10 \%$ after the SSA bias was reduced. 
Atmos. Chem. Phys. Discuss., https://doi.org/10.5194/acp-2017-1104

Manuscript under review for journal Atmos. Chem. Phys.

Discussion started: 4 December 2017

(c) Author(s) 2017. CC BY 4.0 License.

\section{Introduction}

Aerosol Optical Depth (AOD), Single Scattering Albedo (SSA), and asymmetry parameters are important inputs used for calculating the Direct Radiative Forcing (DRF) of aerosols (Iacono et al., 2008). Among aerosol optical properties, the SSA is the factor that most contributes to the uncertainty of the aerosol DRF calculations. Previous studies have suggested that a small change in the SSA can lead to a significant change in the aerosol radiative forcing based on the analysis of in-situ observations, chemical transport and radiative transfer model results, and satellite data (Loeb and Su, 2010; McComiskey et al., 2008; Srivastava et al., 2011). For example, a decrease in the SSA from 0.9 to 0.8 (an $11 \%$ decrease) can often change the sign of the DRF from negative (cooling), to positive (warming) values (Jethva et al., 2014).

Generally, the aerosol SSA is calculated using the Mie theory by assuming the particles are spherical. This spherical assumption may not be applicable to aerosols that have diverse geometrical shapes such as Black Carbon (BC) and soil dust (Mishchenko, 2009). For this reason, previous studies have suggested alternative methods such as the Rayleigh-DebyeGans theory for aggregates (Farias et al., 1996), and the T-matrix method for non-spherical particles (Mishchenko, 2009). However, the Mie theory is still a powerful tool for global model calculations by virtue of its brevity, computational efficiency, and applicability to radiative transfer models. As a result, in a recent Aerosol Comparisons between Observations and Models (AeroCom) study (Myhre et al., 2013b), which was the basis of the fifth assessment report from the Intergovernmental Panel on Climate Change (IPCC) (Myhre et al., 2013a), Mie theory was used in all of the participating models.

The application of Mie theory for aerosol SSA calculations requires precise information about the size distribution, refractive index, particle density, and hygroscopic 
Atmos. Chem. Phys. Discuss., https://doi.org/10.5194/acp-2017-1104

growth factors of aerosols. However, it is difficult to determine these parameters from measurements because the characteristics of aerosols vary widely depending on the region, source, aging and mixing state, and measurement technique. As a result, the input parameters used for aerosol SSA calculations are variable and depend on the corresponding measurements, which can cause a wide range of calculated aerosol SSAs. For example, some previous global modeling studies found that no significant bias existed between calculated SSAs versus Aerosol Robotic Network (AERONET) observations (Chin et al., 2009; Dai et al., 2015), while other studies showed positive biases in the estimates (Feng et al., 2013; Jo et al., 2016; Lin et al., 2014; Myhre et al., 2009). We surmised that the SSA bias could be reduced when models use relatively high $\mathrm{BC}$ emissions and a low BC density. For example,

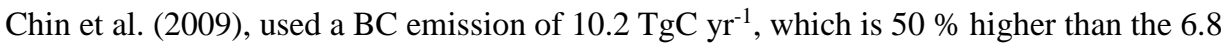

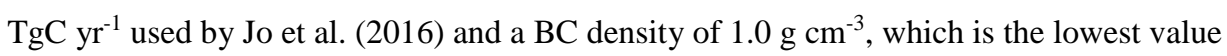
used in the literature (Koch et al., 2009). Since there is limited information available on the emission and physical parameters of the $\mathrm{BC}$ values used in previous studies, we cannot reach

15 a conclusion that explains the range of global SSA values that have been estimated by previous modeling studies. Instead, we mainly focused on the physical parameters affecting the SSA calculation, which are discussed below.

Choosing the appropriate input parameters for Mie calculations is a greater challenge for $\mathrm{BC}$ than for other aerosols, because $\mathrm{BC}$ particles usually exist as agglomerates of primary spherules rather than individual spherical particles (Alexander et al., 2008). As a result, the physical parameters for $\mathrm{BC}$ used in the AeroCom models are variable for the mass median diameter $(0.020-0.852 \mu \mathrm{m})$, density $\left(1.0-2.0 \mathrm{~g} \mathrm{~cm}^{-3}\right)$, and refractive indices $(1.75-0.44 \mathrm{i}-$ 2.0 - 1.0i) (Koch et al., 2009). Furthermore, the SSA may vary significantly depending on the mixing state. Both theoretical and observational studies showed that an SSA value of an 
Atmos. Chem. Phys. Discuss., https://doi.org/10.5194/acp-2017-1104

internally mixed BC aerosol is lower than that of an externally mixed BC (Bond et al., 2006; Drury et al., 2010; Shiraiwa et al., 2008).

Although $\mathrm{BC}$ is a major species contributing to aerosol absorption, soil dust is also an important contributor (Yang et al., 2009). The global mass concentration of soil dust is the largest amongst the other aerosols. Thus, soil dust could have a significant impact on the global SSA, especially since the size distributions of dust are poorly evaluated in global models (Kok, 2011; Kok et al., 2017). Previous studies showed a significant change in the observed SSA (Khatri et al., 2014) and simulated aerosol DRF (Mahowald et al., 2014) as a function of the coarse/fine fractions of soil dust. are typically assumed to be a scattering aerosol, although recent studies have confirmed the presence of this component (Alexander et al., 2008; Kirchstetter and Thatcher, 2012; Laskin et al., 2015). The inclusion of the absorbing OA (known as Brown Carbon, BrC) may have a significant effect on the SSA calculation (Feng et al., 2013; Jo et al., 2016; Lin et al., 2014). mixing state, dust size distributions, and the presence of $\mathrm{BrC}$. We conducted global simulations for the years 2008 - 2010 using a 3-D chemical transport model (GEOS-Chem). First, we extensively evaluated the simulated aerosol mass concentrations and aerosol optical properties by comparing the model with observations from global aerosol observation networks such as the global Aerosol Mass Spectrometer (AMS) dataset, the Surface Particulate Matter Network (SPARTAN), and AERONET for the years 2008 - 2010. Multiple sensitivity simulations were also carried out to examine the effects of individual factors on the calculated SSA as discussed above. Finally, using the simulation results, we estimated the aerosol Direct Radiative Effect (DRE) and its sensitivity to the assumed factors, to provide 
Atmos. Chem. Phys. Discuss., https://doi.org/10.5194/acp-2017-1104

Manuscript under review for journal Atmos. Chem. Phys.

Discussion started: 4 December 2017

(c) Author(s) 2017. CC BY 4.0 License.

insights in the climatic implications of current Global Climate Models (GCMs).

\section{$2 \quad$ Model description}

We used the GEOS-Chem (version 10.1) global 3-D chemical transport model (Bey et

5 al., 2001), which is driven by the Modern Era Retrospective-analysis for Research and Applications (MERRA) assimilated meteorological data from the Global Modeling and Assimilation Office (GMAO) (Rienecker et al., 2011). Meteorological data including temperature, wind, humidity, planetary boundary layer height, and other meteorological variables at $0.5^{\circ} \times 0.667^{\circ}$ horizontal resolutions were re-gridded to $2^{\circ} \times 2.5^{\circ}$ for this study.

$\mathrm{BC}, \mathrm{OA}, \mathrm{SO}_{4}{ }^{2-}, \mathrm{NO}_{3}{ }^{-}, \mathrm{NH}_{4}{ }^{+}$, soil dust, and sea salt aerosols. $\mathrm{BC}$ and $\mathrm{OA}$ were simulated based on the work published by Park et al. (2003). The model simulated BC and Primary OA (POA), with a hydrophobic and a hydrophilic tracer for each. For a Secondary OA (SOA) simulation, we used the scheme developed by Pye et al. (2010), which considers the parent

15 hydrocarbons of monoterpenes, sesquiterpenes, isoprene, and aromatics with $\mathrm{NO}_{\mathrm{x}}$ dependent yields. SOA was considered as hydrophilic, and further details are described in Pye et al. (2010).

For the sensitivity study described in Section 3.4, we additionally considered $\mathrm{BrC}$ by using the $\mathrm{BrC} / \mathrm{OC}$ ratio calculated by Jo et al. (2016). We applied the $\mathrm{BrC} / \mathrm{OC}$ ratio to the simulated POA and SOA of each grid box in order to calculate the BrC from both primary and secondary sources. The ratio of $\mathrm{BrC}$ to $\mathrm{OC}$ burden was 0.19 across the globe, but could be regionally variable as shown in Figure 7 in Jo et al. (2016). The detailed BrC estimation method and the global distributions are described in Jo et al. (2016).

The model simulated inorganic aerosols following the method of Park et al. (2004). 
Atmos. Chem. Phys. Discuss., https://doi.org/10.5194/acp-2017-1104

Manuscript under review for journal Atmos. Chem. Phys.

Discussion started: 4 December 2017

(c) Author(s) 2017. CC BY 4.0 License.

Nitrate aerosol formation was computed using ISORROPIA II (Fountoukis and Nenes, 2007;

Pye et al., 2009), which calculates the $\mathrm{H}_{2} \mathrm{SO}_{4}-\mathrm{HNO}_{3}-\mathrm{NH}_{3}-\mathrm{H}_{2} \mathrm{O}$ thermodynamics. Dust aerosols were simulated using the Dust Entrainment And Deposition (DEAD) scheme of Zender et al. (2003), along with the source function used in GOCART (Ginoux et al., 2001), as presented by Fairlie et al. (2007). The sea salt emission was estimated as a function of dry particle size, local $10 \mathrm{~m}$ wind speed, and sea surface temperature (Alexander et al., 2005; Jaeglé et al., 2011).

We used the anthropogenic emission values of $\mathrm{BC}, \mathrm{OC}, \mathrm{CO}, \mathrm{NO}_{\mathrm{x}}, \mathrm{NH}_{3}$, and $\mathrm{SO}_{2}$ from the Hemispheric Transport of Air Pollution (HTAP) v2 inventory with a horizontal resolution of $0.1^{\circ} \times 0.1^{\circ}$ (Janssens-Maenhout et al., 2015). HTAP v2 includes ships, energy, industry, transport, residential, and agriculture sector data. $\mathrm{For}_{\mathrm{NH}}$, we applied the diurnal variation factors from Zhu et al. (2015) in order to reduce the high bias of nitrate aerosol simulations. Aircraft emission values were considered by using the Aviation Emissions Inventory Code (AEIC) database (Stettler et al., 2011). Anthropogenic emissions of hydrocarbons including benzene, toluene, and xylene were taken from the Reanalysis of the Tropospheric chemical composition (RETRO) inventory (Schultz et al., 2007). Biogenic VOC emissions were taken from the Model of Emissions of Gases and Aerosols from Nature (MEGAN) v2.1 (Guenther et al., 2012). The emissions of the VOCs were computed on the basis of emission activity factors, soil moisture, leaf age, and canopy environment. The Global Fire Emission Database version 4 (GFEDv4) inventory (Giglio et al., 2013) was used for biomass burning emissions at a $0.25^{\circ} \times 0.25^{\circ}$ spatial resolution. The global emission values used in this study are summarized in Table 1. 
Atmos. Chem. Phys. Discuss., https://doi.org/10.5194/acp-2017-1104

Manuscript under review for journal Atmos. Chem. Phys.

Discussion started: 4 December 2017

(c) Author(s) 2017. CC BY 4.0 License.

\section{Aerosol optical property calculation}

\subsection{FlexAOD}

We calculated the AOD, SSA, and asymmetry parameters using the Flexible Aerosol Optical Depth (FlexAOD) tool, which is a GEOS-Chem post-processing tool for aerosol

5 optical property calculations (Curci et al., 2015). FlexAOD uses Mie theory (Mishchenko et al., 2002) with input data including size distributions, refractive indices, particle density, and hygroscopic growth factors included for each aerosol species. Aerosol mixing state and its effects on the AOD, SSA, and asymmetry parameter were also considered. We assumed three different mixing states - external mixing, homogeneous internal mixing, and core-shell

10 internal mixing. Each aerosol was assumed to be formed by a single chemical species in the case of external mixing. Homogeneous internal mixing assumes that all aerosols are well mixed, and the core-shell internal mixing assumes that an insoluble well-mixed core is coated by a concentric well-mixed soluble shell. A detailed description of the aerosol optical property calculation with different mixing states can be found in Section 2 of Curci et al.

15 (2015).

\subsection{Input parameters for FlexAOD}

Table 2 summarizes the input parameters used in the Mie calculation of FlexAOD. The values in Table 2 are the same as the input parameters used in online aerosol optical property and photolysis rate calculations in the standard GEOS-Chem v10.1. Input

20 parameters in GEOS-Chem were initially taken from the Optical Properties of Aerosols and Clouds (OPAC) database (Hess et al., 1998) and Chin et al. (2002), as described in Martin et al. (2003).

Herein, we briefly discuss the significant updates to the method of Martin et al. (2003) that we used in this study. The log-normal distribution was assumed for aerosols except for 
soil dust, which follow the Gamma distribution. The geometric standard deviations of the inorganic aerosols, $\mathrm{OA}$, and $\mathrm{BC}$ were reduced from 2.0 (OPAC) to 1.6 based on measurements from the optical particle counter instrument during the International Consortium for Atmospheric Research on Transport and Transformation (ICARTT) 2004 field campaign (Drury et al., 2010). Inorganic aerosols followed the refractive index and hygroscopic growth factors (HGFs) of water-soluble component (WASO), which were changed from those of sulfate droplets (SUSO) in OPAC. HGFs of OA were updated to 1.35 at $95 \%$ RH based on the chamber and field observations of Jimenez et al. (2009). The geometric mean radius of $\mathrm{BC}$ was $0.020 \mu \mathrm{m}$, which was increased from $0.012 \mu \mathrm{m}$. The density of $\mathrm{BC}$ was increased to $1.8 \mathrm{~g} \mathrm{~cm}^{-3}$ (Bond and Bergstrom, 2006) from $1.0 \mathrm{~g} \mathrm{~cm}^{-3}$ by OPAC (Hess et al., 1998). These BC-related parameter changes led to significant changes in aerosol absorption, which are discussed in the following section.

\subsection{Effects of size distribution and refractive index of $\mathrm{BC}$ on absorption}

As discussed in Section 1, BC particles typically form aggregates (Alexander et al.,

15 2008), which makes it difficult to choose the appropriate BC radius in the Mie calculation (Koch et al., 2009). Here we examined the sensitivity of BC absorption with respect to the choice of geometric mean radius $\left(\mathrm{r}_{\mathrm{g}}\right)$ and geometric standard deviation $(\sigma)$ using Mie theory. Using a BC column concentration of $0.25 \mathrm{mg} \mathrm{m}^{-2}$ we calculated the Absorption AOD (AAOD) for $1-200 \mathrm{~nm}\left(\mathrm{r}_{\mathrm{g}}\right)$ and 1.2, 1.6, and $2.0(\sigma)$ as shown in Figure 1(a). Values were generally within the reported ranges of global mean BC AAODs $\left(0.8 \times 10^{-3}-3.5 \times 10^{-3}\right)$ from the AeroCom phase I models, although we did not consider hygroscopic growth. Red star and blue rectangle symbols indicate OPAC values $\left(\mathrm{r}_{\mathrm{g}}=12 \mathrm{~nm}\right.$ and $\left.\sigma=2.0\right)$ and GEOSChem default size distributions $\left(\mathrm{r}_{\mathrm{g}}=20 \mathrm{~nm}\right.$ and $\left.\sigma=1.6\right)$. We found that the use of these two size distributions led to very similar AAODs ( $<1 \%$ difference), resulting from the combined 
Atmos. Chem. Phys. Discuss., https://doi.org/10.5194/acp-2017-1104

Manuscript under review for journal Atmos. Chem. Phys.

Discussion started: 4 December 2017

(c) Author(s) 2017. CC BY 4.0 License.

effects of the increased $r_{g}$ and decreased $\sigma$.

Figure 1(b) represents the calculated BC AAOD values as a function of real and imaginary refractive indices. BC AAOD values increased as the imaginary refractive index increased and the real refractive index decreased. Red star and blue triangles indicate BC

5 AAOD values using the refractive indices from OPAC $(1.74-0.44 \mathrm{i})$ and Bond and Bergstrom (2006) (1.95 - 0.79i), respectively. BC AAOD values using refractive indices between $1.95-0.79 \mathrm{i}$ were $49 \%$ higher than the values obtained using refractive indices between $1.74-0.44$ i. A similar result was reported by Stier et al. (2007), who also found that their AAOD values when using refractive indices between $1.95-0.79 \mathrm{i}$ were $52 \%$ higher

10 than those found using $1.74-0.44 \mathrm{i}$ in the ECHAM5-HAM model.

\subsection{FlexAOD simulations}

Using the aerosol mass concentrations from the GEOS-Chem simulations above, we carried out a number of FlexAOD simulations by changing the input parameters. Here we focused on $\mathrm{BC}$ because of its high contribution to light absorption and the diverse morphologies found in the atmosphere (Alexander et al., 2008). We examined the sensitivity of the calculated aerosol absorption to the assumed input parameters shown in Table 3. For example, the GEOS case indicates a FlexAOD simulation using GEOS-Chem default values as of v10-01. The OPAC database was used for the OP sensitivity case. Refractive indices between $1.95-0.79 \mathrm{i}$ were used for BB, BBR, and BBHR cases with different geometric

20 radiuses of $\mathrm{BC}$ (Table 3). The geometric mean radius of $0.065 \mu \mathrm{m}$ was adapted from Bond et al. (2013). We additionally assumed a geometric mean radius of $0.1 \mu \mathrm{m}$, which seemed to be higher than that used by previous studies (Bond et al., 2013; Wang et al., 2014), however, the value was still within the range of the AeroCom study (Koch et al., 2009).

After the sensitivity simulations shown in Table 3, we further considered different 
Atmos. Chem. Phys. Discuss., https://doi.org/10.5194/acp-2017-1104

Manuscript under review for journal Atmos. Chem. Phys.

Discussion started: 4 December 2017

(c) Author(s) 2017. CC BY 4.0 License.

mixing states, the effects of brown carbon, and also the observationally constrained dust size distributions. We added tag names for representing these factors. As discussed in Section 3.1, we considered the three mixing states of external, homogeneous internal, and core-shell internal and the corresponding “_E", “_H”, and "_C" tag names were added to base case names in Table 3, respectively. If the sensitivity case includes BrC absorption, the "_BR" tag name was added. We also implemented a new dust size distribution in the model as suggested by Zhang et al. (2013). Zhang et al. (2013), developed the dust size distribution with constraints from in-situ measurements and the work of Kok (2011), who suggested new dust size distributions based on the physics of the scale-invariant fragmentation of brittle materials. The “_DI" tag name was applied when we used the dust size distribution by Zhang et al. (2013). For instance, "GEOS_BR_DI_H" indicates that the model with GEOS-Chem default input parameters, brown carbon, dust size distribution by Zhang et al. (2013), and the homogeneous internal mixing assumption were used.

\section{Model evaluations}

\subsection{Global aerosol mass concentration}

We used the AMS dataset (Zhang et al., 2007) and the SPARTAN observations (Snider et al., 2015) to evaluate the simulated mass concentrations of aerosols globally. Since the observations were available for multiple years (AMS: 2000 2008, SPARTAN: 2013

20 2015), we focused our evaluation on the observed monthly variation using the monthly mean value of the simulation averaged for the years $2008-2010$. Year to year variability was not considered in this study similar to previous studies (Jo et al., 2013; Spracklen et al., 2011; Yu, 2011).

Figure 2 shows point-to-point comparisons of the simulated monthly mean sulfate, 
nitrate, ammonium, and organic aerosol concentrations with the AMS network observations. Statistical parameters including the regression slope, y-intercept (Y-ict), correlation coefficient (R), normalized mean bias (NMB), and root mean square error (RMSE) are presented in Table 4 . We found that the model successfully reproduced the observed inorganic aerosol concentrations with correlation coefficients of $0.62-0.78$ and regression slopes of $0.69-0.84$. Compared to Jo et al. (2013), the model showed an improved performance in terms of statistics (e. g. RMSEs were decreased by $22-45 \%$ ). These improvements are attributed to the different emission inventory values used in this study. In contrast to inorganic aerosols, the model showed a low correlation coefficient (0.36) and a high RMSE $\left(4.77 \mu \mathrm{g} \mathrm{m}^{-3}\right)$ for OA. This result is consistent with the evaluation of OA against AMS found previously in the literature (Jo et al., 2013; Yu, 2011). The low bias ($37 \%$ ) in the model was mainly caused by poor SOA simulations, which still showed a considerable gap from observations as pointed out by the recent AeroCom inter-comparison study for OA (Tsigaridis et al., 2014).

Figure 3 shows the scatter plots of BC, sulfate, nitrate, ammonium, dust, and Particulate Matter with a radius of $2.5 \mu \mathrm{m}\left(\mathrm{PM}_{2.5}\right)$ between SPARTAN observations and the model results. Statistical parameters are also shown in Table 4. We found that the model performance for inorganic aerosols was degraded, especially for nitrate aerosols. Differences in values between observation years is one of the reasons for the discrepancy between the AMS (2000 - 2008) and the SPARTAN (2013 - 2015) dataset model evaluations. During the past decade, $\mathrm{NO}_{\mathrm{x}}$ emissions and column concentrations over the United States and Europe have been decreasing (Curier et al., 2014; Granier et al., 2011; Simon et al., 2014), and the United States and Europe are the main regions covered by the AMS observation network (Zhang et al., 2007). Therefore, there is a possibility that these two different global 
observation networks (AMS and SPARTAN) represent different nitrate concentration levels. We found that the nitrate overestimation mainly occurred over the United States (7 of 19 points above 10:1 line in Figure 3) and South Asia (7 of 19 points above 10:1 line in Figure 3). The nitrate overestimation of GEOS-Chem is consistently reported in previous studies for the United States (Heald et al., 2012; Schiferl et al., 2014; Zhang et al., 2012; Zhu et al., 2013), South Asia (Gu and Liao, 2015), and East Asia (Wang et al., 2013). There have been some efforts to find the possible cause of the nitrate overestimation (e. g. the uptake efficiency of $\mathrm{N}_{2} \mathrm{O}_{5}$ on aerosols, the reaction rate for the formation of nitric acid, dry deposition velocity, boundary layer height, and the uptake of nitric acid on coarse mode dust or sea salt), but this issue is not still resolved (Heald et al., 2012; Zhang et al., 2012; Zhu et al., 2013). Photolysis of nitrate also can reduce the overestimation as recently observed by Ye et al. (2017). An investigation of nitrate overestimation is beyond the scope of this study, and will be conducted in future studies.

Compared to nitrate, the $\mathrm{BC}$ values showed a relatively better result with a regression slope of 0.94 . However, the BC concentration was underestimated by $37 \%$, and the underestimation occurred mainly in Manila (10 of 13 points below 10:1 line in Figure 3). We found that the model grid box corresponding to this site was mostly oceanic (Figure S1). The spatial resolution of the model $\left(2^{\circ} \times 2.5^{\circ}\right)$ was too coarse to capture local sources on the island.

For the comparison of dust, we inferred the observed dust mass concentrations following the SPARTAN speciation of Snider et al. (2016). They calculated the dust mass by multiplying $[\mathrm{Al}+\mathrm{Fe}+\mathrm{Mg}]$ by 10 based on the elemental composition of natural dust presented by Wang (2015). Although this calculation seems oversimplified, we found that the method of Snider et al. (2016) was similar to the method of Malm et al. (1994) for estimating 
Atmos. Chem. Phys. Discuss., https://doi.org/10.5194/acp-2017-1104

Manuscript under review for journal Atmos. Chem. Phys.

Discussion started: 4 December 2017

(c) Author(s) 2017. CC BY 4.0 License.

dust mass concentrations based on the observed trace metal concentrations (regression slope of 1.0 and correlation of 0.98$)$.

Simulated $\mathrm{PM}_{2.5}$ concentrations were generally in good agreement with the observations $(\mathrm{R}=0.76)$ with a slight low bias observed for the mean concentrations $(-24 \%)$.

5 The performance of the model was comparable to that of global $\mathrm{PM}_{2.5}$ estimates constrained by using satellite AOD observations $(\mathrm{R}=0.73-0.81$ and regression slopes of $0.68-0.96)$ (van Donkelaar et al., 2015), which provides confidence in the model's ability to reproduce the AOD and SSA values.

\subsection{AOD and SSA}

The model appeared to appropriately capture the spatial and temporal (monthly) variability of the observed $\mathrm{PM}_{2.5}$ described above. This may result from the combination of the nitrate overestimation and the OA underestimation. To ensure the reliability of the model for the AOD and the SSA evaluation in this section, we also selected simulated results at AERONET sites, which met the following criteria: (1) Differences between the monthly mean observed and simulated concentrations of each aerosol species (inorganics, OA, BC, and dust) should be less than a factor of two at surface networks (AMS and SPARTAN). (2) AERONET and AMS (or SPARTAN) sites should be in the same model grid or adjacent model grids. We could have applied stricter criteria for our data selection, but too few data were available for the analysis. Our conclusions, however, were found not to be sensitive to the criteria used as discussed below.

Figure 4(a) shows the scatterplot of the simulated versus observed AOD at $500 \mathrm{~nm}$ using the base case (GEOS_E). We found that the statistics of the AOD evaluation were very similar to that of the $\mathrm{PM}_{2.5}$. The slopes were 0.68 and 0.70 , the correlation coefficient was 0.76, and the Normalized Mean Biases (NMBs) were $-20 \%$ and $-24 \%$, for AOD and $\mathrm{PM}_{2.5}$, 
respectively. From this result, we concluded that the aerosol optical property calculation in FlexAOD was properly performed. When we filtered out data at AERONET sites using the criteria above, the model showed improved statistics against the observations. The NMB was reduced to $-10 \%$, and the correlation coefficient was increased to 0.82 (Figure 4(b)). sites for $440 \mathrm{~nm}$ and $870 \mathrm{~nm}$. Here we excluded SSA values when the AOD was less than 0.4 because the AERONET SSA retrieval showed high uncertainty for low AOD conditions (Dubovik et al., 2002). The model appropriately simulated the SSA at $870 \mathrm{~nm}$ in common with the evaluation of the AOD at $500 \mathrm{~nm}$, but significantly overestimated the observed SSA at $440 \mathrm{~nm}$. The SSA of the model (0.949) was higher than that of the AERONET (0.897) by 0.052. In other words, the model underestimated the observed absorption (1-SSA) by $-50 \%$. Although the model underestimated $\mathrm{BC}$ by $-37 \%$, the model also underestimated scattering aerosols $\left(\mathrm{PM}_{2.5}\right.$ minus BC) by $-23 \%$. Therefore, the SSA overestimation could be caused by other factors than the underestimation of the $\mathrm{BC}$ mass concentration. This overestimation is similar to the result by Jo et al. (2016), who also found significant SSA overestimation of the GEOS-Chem version 9.1.2 against AERONET. The reasons for this overestimation will be investigated in following sections.

Figure 5(c) and 5(d) represent comparison results similar to Figure 5(a, b) but use only selected data. The model showed an improved result especially for the SSA at $440 \mathrm{~nm}$.

20 The correlation was increased to 0.5 from 0.34 , which is analogous to the evaluated result of the AOD at $500 \mathrm{~nm}$. From these results, we concluded that the model simulation capability of the AOD and SSA was improved when we selected AERONET sites where the model showed good results against the AMS and SPARTAN network. Hereafter, we used these selected AERONET sites for the sensitivity studies below. 


\section{$5 \quad$ SSA sensitivity}

In this section, we present the sensitivity analysis of the calculated SSA values for three factors including the aerosol mixing states, the inclusion of $\mathrm{BrC}$, and dust size distributions. The sensitivity of the $\mathrm{BC}$ physical properties were also investigated but did not show significant differences (Figure S2). We compared the calculated values against the observed SSA at 440 and $870 \mathrm{~nm}$ from AERONET sites across the globe. We thoroughly examined the statistics of the simulated values versus the observed SSA for the ensemble of AERONET sites in this section in order to determine the best parameters for the global SSA estimation.

The effects of the BC internal mixing on the SSA calculation are shown in Figure 6. We found that both homogeneous (Figure 6(a)) and core-shell (Figure 6(b)) internal mixing assumptions led to a significant decrease of the SSA $(0.842-0.851)$ at $440 \mathrm{~nm}$. Furthermore, the NMBs of the AOD were decreased to $-52 \%$ with the internal mixing cases (GEOS_H and GEOS_C) from $-10 \%$ with the external mixing case (GEOS_E) (Table S1). The decreased internal mixing AODs compared to the external mixing decreased by $-34--37 \%$ because of the decrease of the aerosol numbers with the increased size of each aerosol, which is consistent with previously published results by Curci et al. (2015).

The inclusion of the BrC absorption (GEOS_BR_E) and the use of the dust size distribution presented by Zhang et al. (2013) (GEOS_DI_E) also reduced the SSA overestimation (Figure 6(c-d)). The mean SSAs were decreased by $0.008-0.015$. The regression slope also increased from 0.38 to between $0.55-0.67$. The correlation slightly increased for the GEOS_BR_E case (0.56), but decreased for the GEOS_DI_E case as a result of the more widely scattered points that were affected by high dust concentrations. In contrast to the internal mixing results above, the AOD was not significantly decreased (-7 \% 
Atmos. Chem. Phys. Discuss., https://doi.org/10.5194/acp-2017-1104

Manuscript under review for journal Atmos. Chem. Phys.

Discussion started: 4 December 2017

(c) Author(s) 2017. CC BY 4.0 License.

$-1 \%$ ) with respect to the GEOS_E case.

Figure 7 shows the combined effects of both the $\mathrm{BrC}$ absorption and the dust size distribution on the $440 \mathrm{~nm}$ SSA calculation. All four sensitivity cases showed improved results although the overestimation of the SSA still existed in the model. We speculate that this remaining gap could be reduced when we consider strongly absorbing $\mathrm{BrC}$ as some studies have reported (Alexander et al., 2008; Chung et al., 2012). However, it is too uncertain whether the strongly absorbing $\mathrm{BrC}$ is dominant globally. The reported $\mathrm{BrC}$ absorptions vary by two orders of magnitude (Jo et al., 2016) and further studies are needed to clarify the presence of strongly absorbing $\mathrm{BrC}$. decreased as the radius of $\mathrm{BC}$ increased. We surmised that the use of a spherule size radius $(\sim 0.02 \mu \mathrm{m})$ seemed more appropriate than the aggregate size radius $(\sim 0.1 \mu \mathrm{m})$ for the calculations using Mie theory. However, the result can be affected by many factors, and therefore it is difficult to generalize the use of the radius in this study. for the SSA at $870 \mathrm{~nm}$ (Figure 8). Aerosol absorption at $870 \mathrm{~nm}$ is mainly affected by BC rather than $\mathrm{BrC}$ and dust (Yang et al., 2009). Therefore, the differences are mainly attributed to the size distributions and the refractive indices of the BC. Since BC is the only contributor to aerosol absorption at $870 \mathrm{~nm}$, we found that the effects of the $\mathrm{BC}$ refractive index on the

20 SSA were more important for the $870 \mathrm{~nm}$ than for the $440 \mathrm{~nm}$ results. The $870 \mathrm{~nm}$ SSA decreased by the use of higher refractive index (BB_BR_DI_E - GEOS_BR_DI_E) was 0.017, the absolute magnitude of which is larger than the $440 \mathrm{~nm}$ SSA decrease of -0.011 (Table 6).

Considering all the evaluations for the AOD and SSA above, we found that the 
Atmos. Chem. Phys. Discuss., https://doi.org/10.5194/acp-2017-1104

Manuscript under review for journal Atmos. Chem. Phys.

Discussion started: 4 December 2017

(c) Author(s) 2017. CC BY 4.0 License.

GEOS_BR_DI_E case showed the best performance against AERONET observations. In the following section, we used this case for the DRE calculation and calculated the effects of the sensitivity factors on the DRE change.

\section{$5 \quad 6 \quad$ Implication for global DRE}

Here we calculated the global clear-sky DRE of selected sensitivity simulations in Figure 9 by using the Rapid Radiative Transfer Model for General Circulation Models (RRTMGs) (Iacono et al., 2008). MERRA reanalysis data were used for albedo and other meteorological variables. the years 2008 - 2010. Globally, annual mean DREs are negative except for Northern Africa where weakly absorbing dust concentrations were very high. The absolute magnitudes of the DRE were high in regions with heavy biomass burning (Central Africa) and anthropogenic (East Asia) emissions. These global distributions are similar to the results presented by Heald et al. (2014) (Figure 3 in their paper). The annual mean DRE was $-2.62 \mathrm{~W} \mathrm{~m}^{-2}$, which is also comparable to the annual mean DRE $\left(-2.75 \mathrm{~W} \mathrm{~m}^{-2}\right)$ for 2010 published by Heald et al. (2014).

The inclusion of the $\mathrm{BrC}$ absorption increased the DRE by $0.07 \mathrm{~W} \mathrm{~m}^{-2}$, especially for regions with high biomass burning (Africa) and biofuel (Asia) emissions (Jo et al., 2016) as shown in Figure 9(e). Note that the $\mathrm{BrC}$ absorption could be underestimated in this study as discussed in Section 5, and in turn, the DRE increased by $\mathrm{BrC}$ could be underestimated. The DRE increase after modifying the dust size distribution was $0.17 \mathrm{~W} \mathrm{~m}^{-2}$ (Figure 9(f)), which is more than two times higher than the DRE increase by $\mathrm{BrC}$ absorption. When we considered both the $\mathrm{BrC}$ absorption and the observationally constrained dust size distribution, the increment of the DRE was $0.26 \mathrm{~W} \mathrm{~m}^{-2}$ (Figure $9(\mathrm{~g})$ ), which accounts for $10 \%$ of the DRE 
Atmos. Chem. Phys. Discuss., https://doi.org/10.5194/acp-2017-1104

Manuscript under review for journal Atmos. Chem. Phys.

Discussion started: 4 December 2017

(c) Author(s) 2017. CC BY 4.0 License.

of the reference case.

The inclusion of the $\mathrm{BrC}$ absorption (-0.015) led to a more effective decrease of the SSA at $440 \mathrm{~nm}$ than the change of dust size distribution (-0.008) as shown in Table 5.

However, the effects on the DRE were different. The relatively higher DRE change $(0.17 \mathrm{~W}$

$5 \mathrm{~m}^{-2}$ ) shown in Figure 9(f) is mainly caused by high dust burden (14.4 Tg), which was $10-$ 100 times higher than the $\mathrm{BC}(0.1 \mathrm{Tg})$, or OA $(1.4 \mathrm{Tg})$ burden. Note that the DRE is calculated by using the AOD ( proportional to burden) as well as the SSA. Therefore, we conclude that the size distribution of dust plays an important role in the modelled DRE estimation, as also reported by Kok et al. (2017).

10

\section{$7 \quad$ Conclusions}

Although we found that the GEOS_BR_DI_E case showed the best performance against the AERONET AOD and SSA, it is difficult to confirm whether this result can be applied to other studies. There were many factors simultaneously affecting the AOD and SSA

15 calculation such as the hygroscopic growth factor, which was not discussed in detail.

However, we were able to identify some notable findings that could apply to future modeling studies when using Mie theory for the calculation of aerosol optical properties:

1. There were no significant differences between the calculated BC absorptions using input parameters from the OPAC database and data from Bond and Bergstrom (2006). The

20 refractive indices used by Bond and Bergstrom (2006) (1.95 - 0.79i) were higher than those used by OPAC (1.74 - 0.44i), and the resulting BC absorption of Bond and Bergstrom (2006) was $49 \%$ higher than that of OPAC. However, the low BC particle density of OPAC (1.0 g $\mathrm{cm}^{-3}$ ) increased the $\mathrm{BC}$ number concentration and the AOD, which enhanced the $\mathrm{BC}$ absorption. We found that the mean SSA of OP_E (0.927) was slightly lower than that of 
Atmos. Chem. Phys. Discuss., https://doi.org/10.5194/acp-2017-1104

BB_E (0.934) (Table 5). Although many previous studies did not provide the BC density they used for the Mie calculation (Feng et al., 2013; Jo et al., 2016; Lin et al., 2014), an assumed BC density was critical to the SSA calculation and should be provided in future intercomparison studies.

5 2. The model using the external mixing assumption showed better performance than the model using internal mixing assumptions in a global modeling sense. Drury et al. (2010), also showed similar results against aircraft observations. The internal mixing assumptions caused very high absorption and an underestimation of the AERONET SSA. The effect of internal mixing on absorption could be overestimated in the model calculations; Cappa et al. (2012) reported that the observed ambient $\mathrm{BC}$ absorption enhancements obtained by internal mixing were small ( $\sim 6 \%)$, which is less than predicted from theoretical calculations and observed from laboratory measurements. Furthermore, $\mathrm{BC}$ absorption enhancement by internal mixing could vary by region (Liu et al., 2015). Coating thickness could also be different due to aging timescales and the distance of source regions. Further observational and modeling studies are needed especially for considering region-specific absorption enhancement.

3. The modelled SSA calculations from previous studies were mostly evaluated between 440 - $550 \mathrm{~nm}$ (Dai et al., 2015; Jo et al., 2016; Lin et al., 2014). However, SSAs at both shorter and longer wavelengths should be evaluated together for the model evaluation. The calculated SSA could show different performances at different wavelengths because they are affected by

20 different aerosols and wavelength-dependent physical characteristics.

4. BrC absorption and observationally constrained dust size distributions should be considered for the SSA calculation in the model, especially for the shorter wavelengths.

These factors reduced the SSA at shorter wavelengths, resulting in a decrease of the positive SSA bias at $440 \mathrm{~nm}$ generally found in global models. 
Atmos. Chem. Phys. Discuss., https://doi.org/10.5194/acp-2017-1104

Manuscript under review for journal Atmos. Chem. Phys.

Discussion started: 4 December 2017

(c) Author(s) 2017. CC BY 4.0 License.

5. The changes of dust size distribution led to a significant increase of the global DRE, whose value $\left(0.17 \mathrm{~W} \mathrm{~m}^{-2}\right)$ was more than two times higher than the global DRE increase by $\mathrm{BrC}$ absorption $\left(0.07 \mathrm{~W} \mathrm{~m}^{-2}\right)$. Global models likely underestimate the global dust DRE because of the overestimation of fine mode dust and the underestimation of the coarse mode dust as shown by Kok et al. (2017), who constrained the global dust size distribution using global observations and models.

\section{Acknowledgements}

We would like to thank the SPARTAN project for establishing and maintaining the

10 SPARTAN sites used in this investigation. The SPARTAN network was initiated with funding from the Natural Sciences and Engineering Research Council of Canada. We thank the principal investigators and their staff for establishing and maintaining the AERONET sites used in this study. We also want to thank Q. Zhang and D. V. Spracklen for providing the global AMS data. This study was supported by the Korea Ministry of Environment as

15 "Climate Change Correspondence Program" and "Public Technology Program based on Environmental Policy” (2017000160001). 
Atmos. Chem. Phys. Discuss., https://doi.org/10.5194/acp-2017-1104

Manuscript under review for journal Atmos. Chem. Phys.

Discussion started: 4 December 2017

(c) Author(s) 2017. CC BY 4.0 License.
Atmospheric

Chemistry

and Physics

Discussions

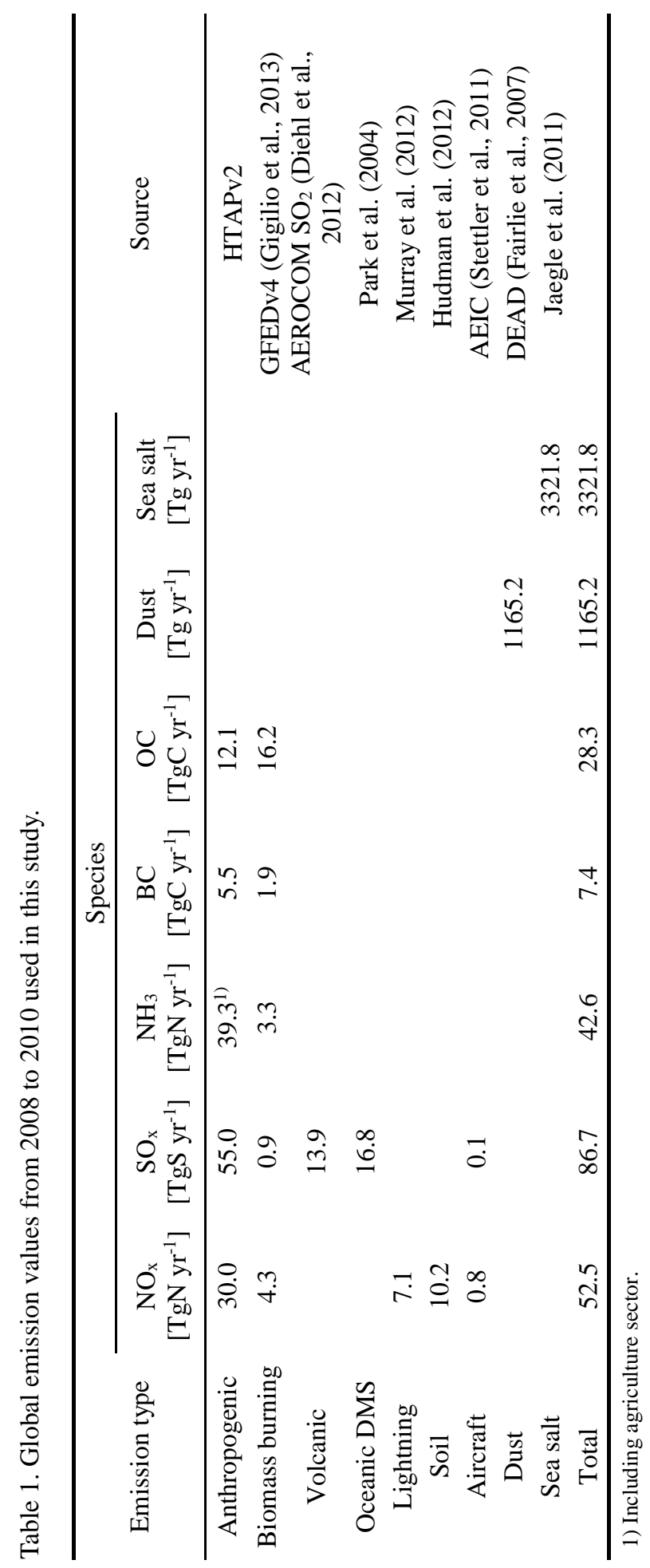


Atmos. Chem. Phys. Discuss., https://doi.org/10.5194/acp-2017-1104

Manuscript under review for journal Atmos. Chem. Phys.

Discussion started: 4 December 2017

(c) Author(s) 2017. CC BY 4.0 License.
Atmospheric

Chemistry

and Physics

Discussions

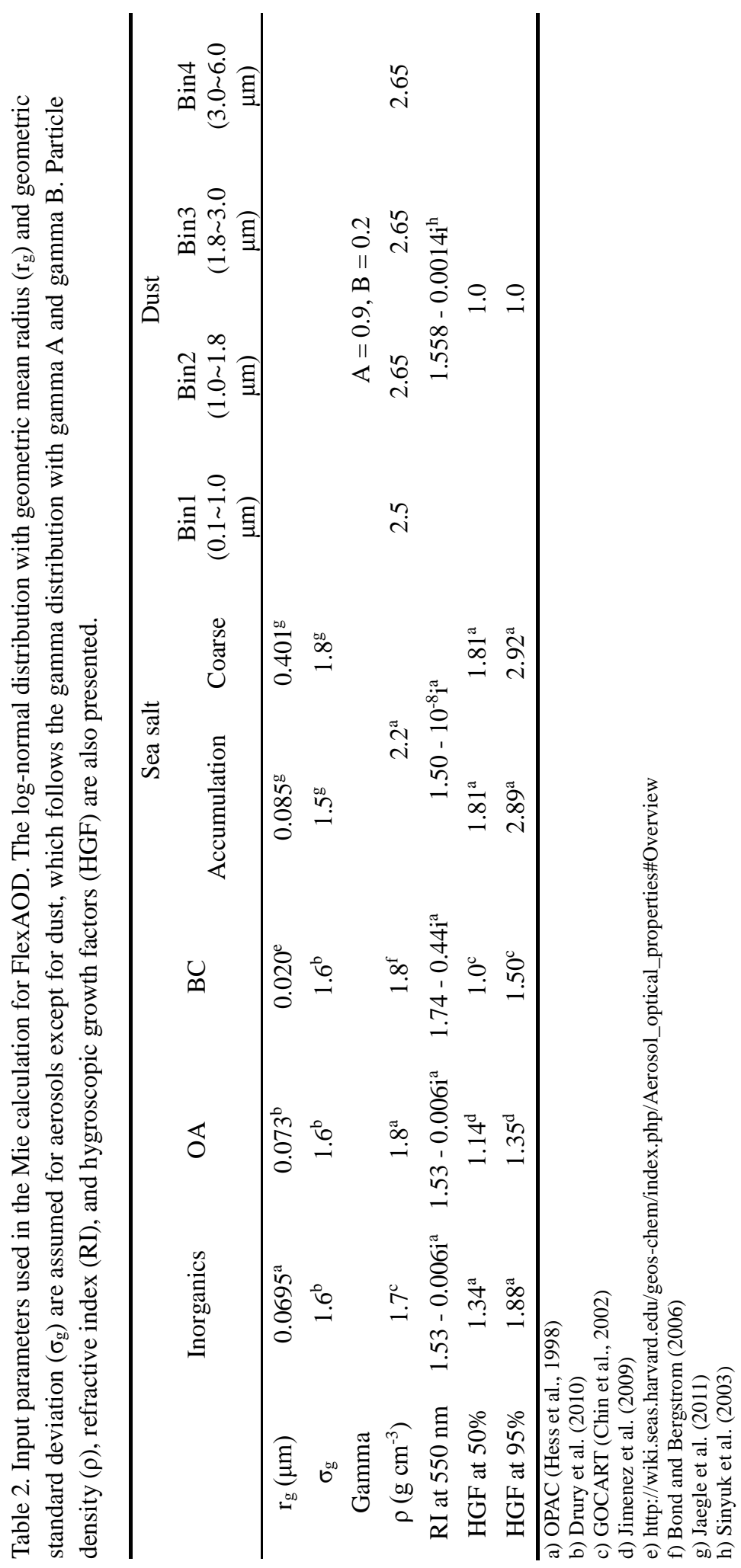


Atmos. Chem. Phys. Discuss., https://doi.org/10.5194/acp-2017-1104

Manuscript under review for journal Atmos. Chem. Phys.

Discussion started: 4 December 2017

(c) Author(s) 2017. CC BY 4.0 License.

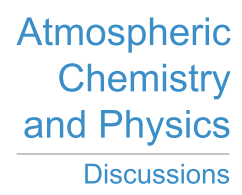

(c) (i)

Table 3. Sensitivity simulation input parameters of BC cases used in this study.

\begin{tabular}{ccccc}
\hline Case & $\begin{array}{c}\text { Refractive } \\
\text { index }\end{array}$ & $\begin{array}{c}\text { Mean Radius } \\
{[\mu \mathrm{m}]}\end{array}$ & Sigma & $\begin{array}{c}\text { Density } \\
{\left[\mathrm{g} \mathrm{cm}^{-3}\right]}\end{array}$ \\
\hline GEOS & $1.74-0.44 \mathrm{i}$ & 0.02 & 1.6 & 1.8 \\
OP & $1.74-0.44 \mathrm{i}$ & 0.0118 & 2.0 & 1.0 \\
BB & $1.95-0.79 \mathrm{i}$ & 0.02 & 1.6 & 1.8 \\
BBR & $1.95-0.79 \mathrm{i}$ & 0.065 & 1.6 & 1.8 \\
BBHR & $1.95-0.79 \mathrm{i}$ & 0.1 & 1.6 & 1.8 \\
\hline
\end{tabular}


Atmos. Chem. Phys. Discuss., https://doi.org/10.5194/acp-2017-1104

Manuscript under review for journal Atmos. Chem. Phys.

Discussion started: 4 December 2017

(c) Author(s) 2017. CC BY 4.0 License.

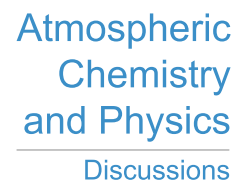

Table 4. Statistical parameters for the evaluation of the model against global aerosol mass concentration observation networks. Regressions slopes and Y-intercepts were computed using the reduced-major-axis method (Hirsch and Gilroy, 1984).

\begin{tabular}{ccccccc}
\hline Network & Species & Slope & Y-ict & R & NMB & RMSE \\
\hline \multirow{5}{*}{ AMS } & Sulfate & 0.77 & 1.31 & 0.78 & 0.17 & 2.25 \\
& Nitrate & 0.84 & 0.68 & 0.62 & 0.40 & 2.04 \\
& Ammonium & 0.69 & 0.71 & 0.78 & 0.21 & 1.18 \\
& Organics & 0.59 & 0.18 & 0.36 & -0.37 & 4.77 \\
\hline \multirow{5}{*}{ SPARTAN } & BC & 0.94 & -0.80 & 0.47 & -0.37 & 2.20 \\
& Sulfate & 0.75 & 1.02 & 0.48 & -0.05 & 3.84 \\
& Nitrate & 3.60 & 0.45 & 0.68 & 2.92 & 7.66 \\
& Ammonium & 1.72 & 0.48 & 0.59 & 1.01 & 3.03 \\
& Dust & 1.14 & -1.88 & 0.38 & -0.25 & 6.00 \\
& PM $_{2.5}$ & 0.70 & 2.37 & 0.76 & -0.24 & 21.65 \\
\hline
\end{tabular}


Atmos. Chem. Phys. Discuss., https://doi.org/10.5194/acp-2017-1104

Manuscript under review for journal Atmos. Chem. Phys.

Discussion started: 4 December 2017

(c) Author(s) 2017. CC BY 4.0 License.

Table 5. Statistical parameters for the comparison between the simulated and the observed SSA at $440 \mathrm{~nm}$ for AOD > 0.4. The observed mean SSA was 0.888 .

\begin{tabular}{rcccccc}
\hline \multicolumn{1}{c}{ Cases } & Slope & Yict & R & RMSE & Mean & Mean bias \\
\hline GEOS_E & 0.38 & 0.60 & 0.50 & 0.061 & 0.944 & 0.057 \\
OP_E & 0.53 & 0.45 & 0.52 & 0.045 & 0.927 & 0.039 \\
BB_E & 0.45 & 0.53 & 0.53 & 0.051 & 0.934 & 0.046 \\
BBR_E & 0.38 & 0.61 & 0.49 & 0.061 & 0.944 & 0.057 \\
BBHR_E & 0.39 & 0.61 & 0.38 & 0.069 & 0.952 & 0.064 \\
\hline GEOS_H & 2.18 & -1.08 & 0.13 & 0.070 & 0.851 & -0.037 \\
GEOS_C & 2.03 & -0.96 & 0.14 & 0.072 & 0.842 & -0.045 \\
OP_H & 2.98 & -1.83 & 0.07 & 0.110 & 0.812 & -0.076 \\
OP_C & 2.53 & -1.43 & 0.09 & 0.099 & 0.817 & -0.071 \\
\hline GEOS_BR_E & 0.55 & 0.44 & 0.56 & 0.046 & 0.929 & 0.041 \\
GEOS_DI_E & 0.67 & 0.34 & 0.34 & 0.055 & 0.936 & 0.049 \\
\hline GEOS_BR_DI_E & 0.70 & 0.30 & 0.53 & 0.039 & 0.920 & 0.032 \\
BB_BR_DI_E & 0.75 & 0.24 & 0.57 & 0.031 & 0.909 & 0.021 \\
BBR_BR_DI_E & 0.69 & 0.31 & 0.52 & 0.039 & 0.920 & 0.032 \\
BBHR_BR_DI_E & 0.68 & 0.32 & 0.46 & 0.047 & 0.928 & 0.040 \\
\hline
\end{tabular}


Atmos. Chem. Phys. Discuss., https://doi.org/10.5194/acp-2017-1104

Manuscript under review for journal Atmos. Chem. Phys.

Discussion started: 4 December 2017

(c) Author(s) 2017. CC BY 4.0 License.
Atmospheric

Chemistry

and Physics

Discussions

at $870 \mathrm{~nm}$ for AOD > 0.4. The observed mean SSA was 0.918 .

\begin{tabular}{rcccccc}
\hline \multicolumn{1}{c}{ Cases } & Slope & Yict & R & RMSE & Mean & Mean bias \\
\hline GEOS_E & 1.17 & -0.16 & 0.76 & 0.026 & 0.923 & 0.005 \\
OP_E & 1.63 & -0.60 & 0.77 & 0.041 & 0.898 & -0.020 \\
BB_E & 1.45 & -0.42 & 0.77 & 0.033 & 0.908 & -0.010 \\
BBR_E & 1.49 & -0.46 & 0.77 & 0.035 & 0.904 & -0.014 \\
BBHR_E & 1.35 & -0.33 & 0.77 & 0.029 & 0.912 & -0.006 \\
\hline GEOS_H & 1.58 & -0.56 & 0.70 & 0.043 & 0.898 & -0.020 \\
GEOS_C & 1.83 & -0.81 & 0.73 & 0.063 & 0.871 & -0.047 \\
OP_H & 2.09 & -1.05 & 0.72 & 0.071 & 0.868 & -0.050 \\
OP_C & 2.28 & -1.25 & 0.74 & 0.093 & 0.843 & -0.075 \\
\hline GEOS_BR_E & 1.16 & -0.14 & 0.76 & 0.025 & 0.923 & 0.005 \\
GEOS_DI_E & 1.15 & -0.14 & 0.79 & 0.024 & 0.913 & -0.005 \\
\hline GEOS_BR_DI_E & 1.10 & -0.10 & 0.79 & 0.024 & 0.909 & -0.009 \\
BB_BR_DI_E & 1.37 & -0.37 & 0.79 & 0.038 & 0.892 & -0.026 \\
BBR_BR_DI_E & 1.41 & -0.40 & 0.80 & 0.041 & 0.889 & -0.029 \\
BBHR_BR_DI_E & 1.27 & -0.27 & 0.80 & 0.033 & 0.897 & -0.021 \\
\hline
\end{tabular}



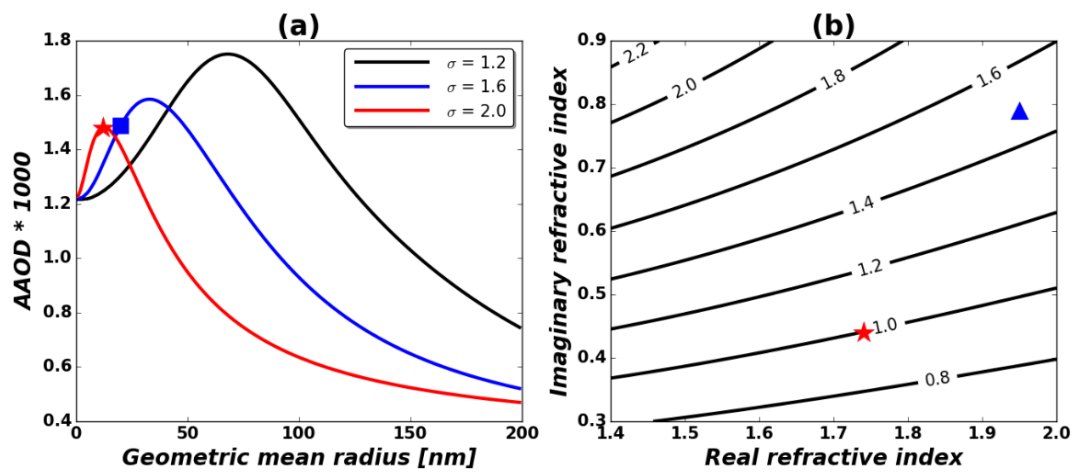

Figure 1. (a) Calculated BC AAOD at $550 \mathrm{~nm}$ (y-axis) as a function of geometric mean radius $\left(\mathrm{r}_{\mathrm{g}}\right)[\mathrm{nm}](\mathrm{x}$-axis). Three different geometric standard deviations $(\sigma)$ are assumed -1.2 (black line), 1.6 (blue line), and 2.0 (red line). Red star and blue rectangle symbols indicate OPAC $\left(\mathrm{r}_{\mathrm{g}}\right.$ $5=12 \mathrm{~nm}$ and $\sigma=2.0)$ and GEOS-Chem default conditions ( $\mathrm{rg}_{\mathrm{g}}=20 \mathrm{~nm}$ and $\left.\sigma=1.6\right)$, respectively. Refractive indices of $1.95-0.79 \mathrm{i}$ were used for this calculation. (b) Calculated BC AAOD (multiplied by 1000, contour line) as a function of the real refractive index (x-axis) and the imaginary refractive index (y-axis). Red star and blue triangle symbols represent BC AAODs using refractive indices by OPAC (1.74 - 0.44i) and Bond and Bergstrom (2006) (1.95 - 0.79i), respectively ( $\mathrm{r}_{\mathrm{g}}$ of $20 \mathrm{~nm}$ and $\sigma$ of 1.6 were assumed in this calculation). For both plots, a BC column concentration of $0.25 \mathrm{mg} \mathrm{m}^{-2}$ and particle density of $1.8 \mathrm{~g} \mathrm{~cm}^{-3}$ were used. Hygroscopic growth was not accounted for in this calculation. 
Atmos. Chem. Phys. Discuss., https://doi.org/10.5194/acp-2017-1104

Manuscript under review for journal Atmos. Chem. Phys.

Discussion started: 4 December 2017

(c) Author(s) 2017. CC BY 4.0 License.

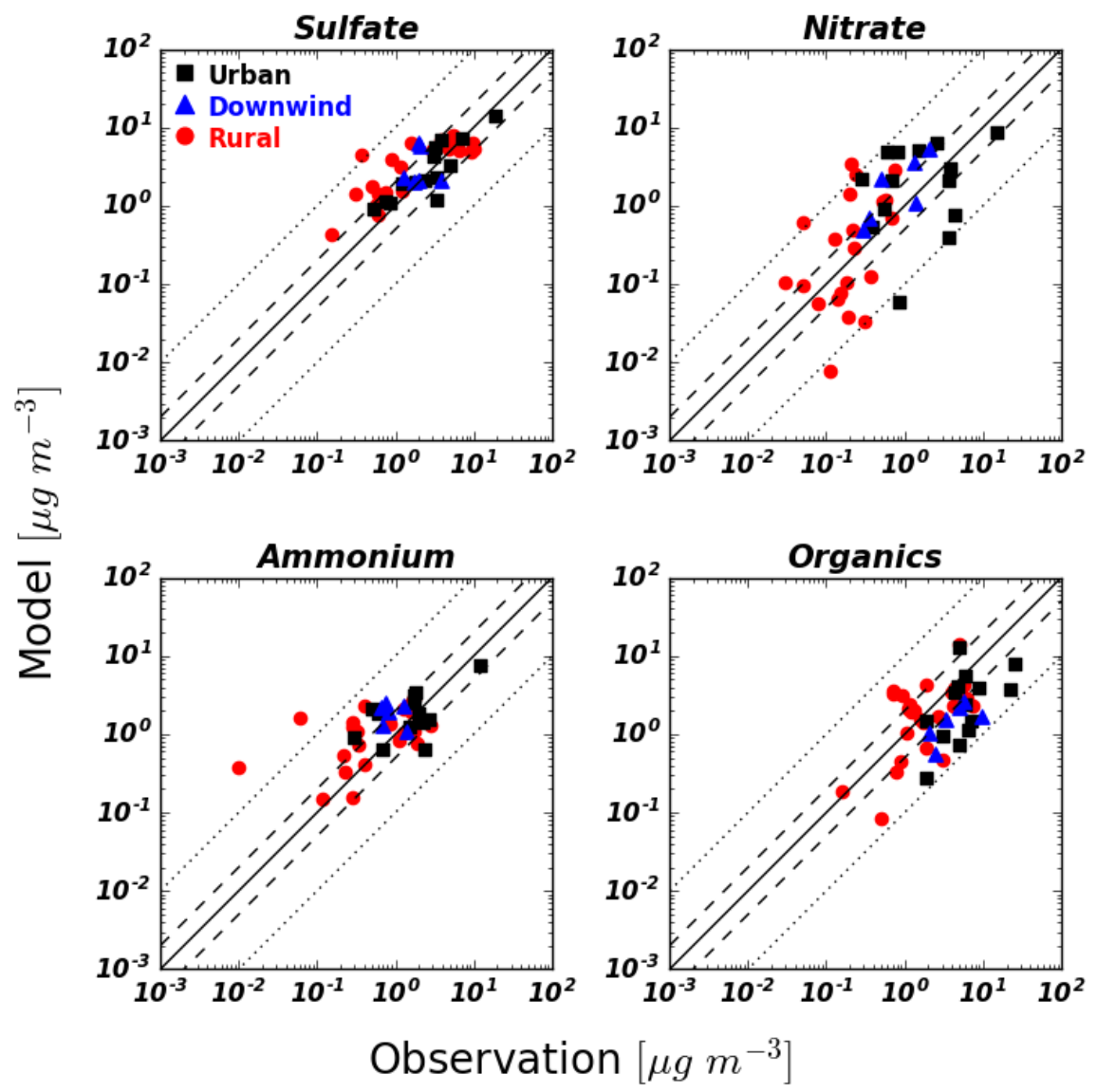

Figure 2. Point-to-point comparisons of the simulated sulfate, nitrate, ammonium, and organics against the AMS network observations. We multiplied the organic matter to organic carbon ratio of 2.1 to organics to account for the non-carbon mass. The 1:1 line (solid), 2:1 lines (dashed), 10:1 lines (dotted) are indicated. 
Atmos. Chem. Phys. Discuss., https://doi.org/10.5194/acp-2017-1104

Manuscript under review for journal Atmos. Chem. Phys.

Discussion started: 4 December 2017

(c) Author(s) 2017. CC BY 4.0 License.
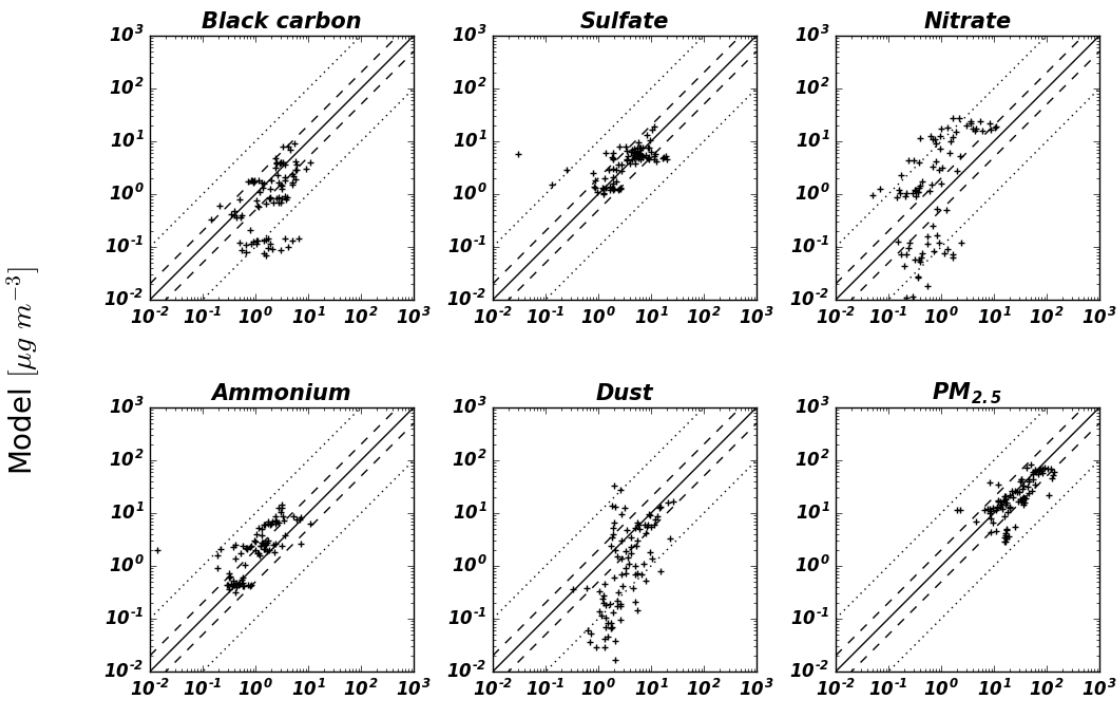

Observation $\left[\mathrm{\mu g} \mathrm{m}^{-3}\right]$

Figure 3. Scatter plots of BC, sulfate, nitrate, ammonium, dust, and $\mathrm{PM}_{2.5}$ between SPARTAN observations (x-axis) and the model (y-axis). The 1:1 line (solid), 2:1 lines (dashed), 10:1 lines (dotted) are indicated. 
Atmos. Chem. Phys. Discuss., https://doi.org/10.5194/acp-2017-1104

Manuscript under review for journal Atmos. Chem. Phys.

Discussion started: 4 December 2017

(c) Author(s) 2017. CC BY 4.0 License.
Atmospheric 을

Chemistry

and Physics

Discussions

(c) (1)
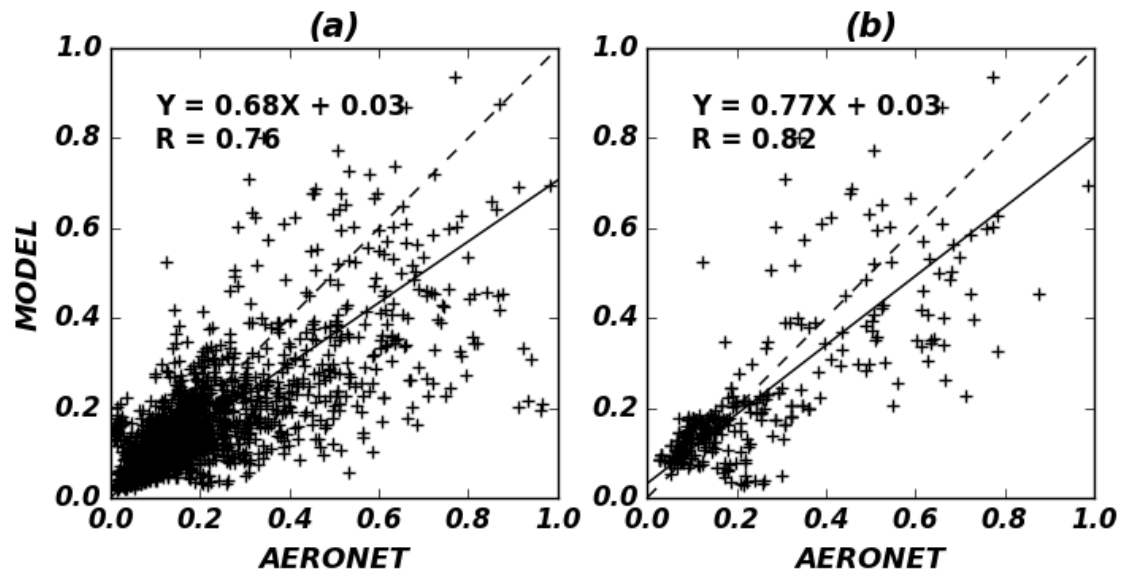

Figure 4. Scatter plot of simulated versus observed AOD at $500 \mathrm{~nm}$ from 2008 - 2010 for (a) all AERONET points and (b) AERONET points constrained by model evaluation against the AMS and SPARTAN network. Reduced major axis regression is shown along with the regression equation and R. Each point indicates monthly averaged AOD when the number of observation was greater than 10 days. 
Atmos. Chem. Phys. Discuss., https://doi.org/10.5194/acp-2017-1104

Manuscript under review for journal Atmos. Chem. Phys.

Discussion started: 4 December 2017

(C) Author(s) 2017. CC BY 4.0 License.
Atmospheric

Chemistry

and Physics

Discussions
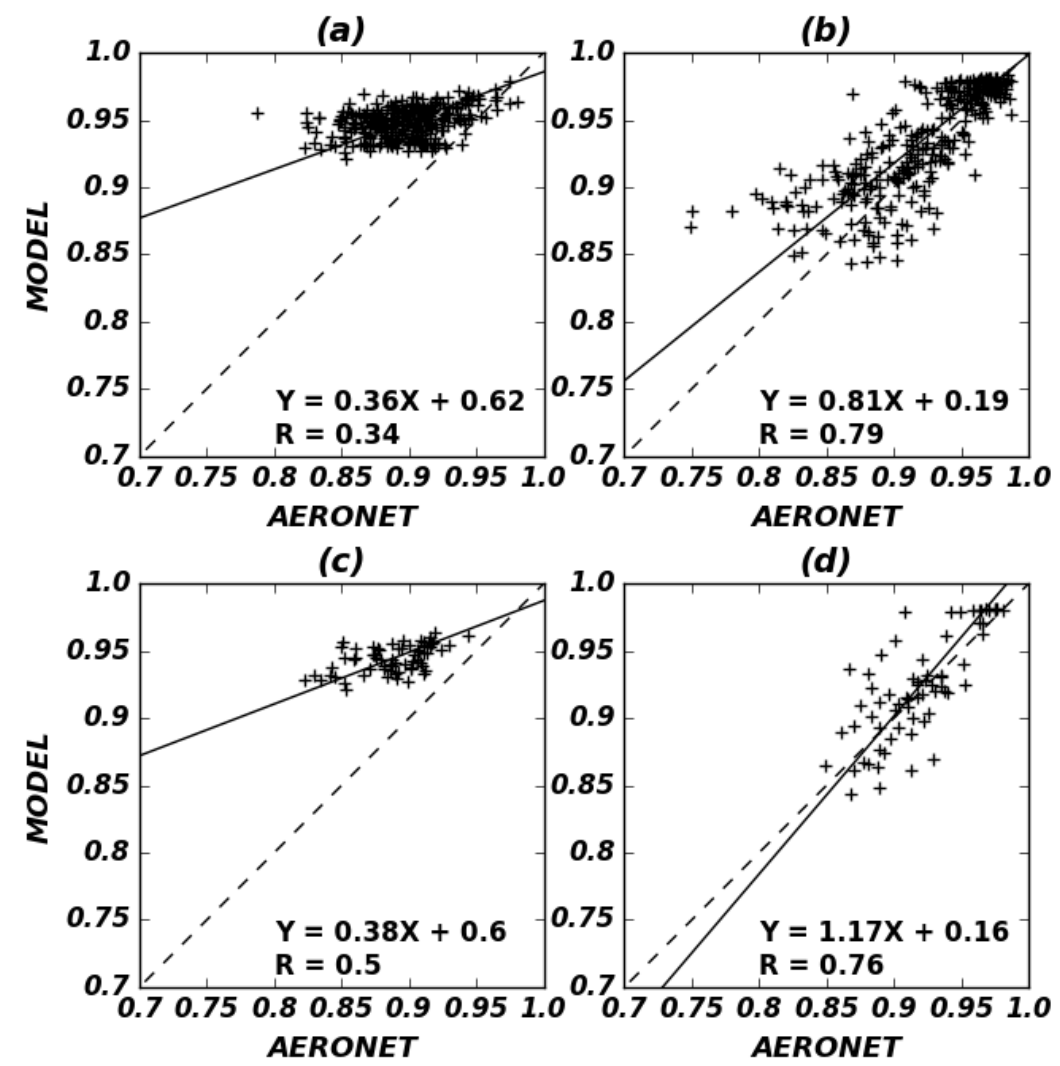

(d)

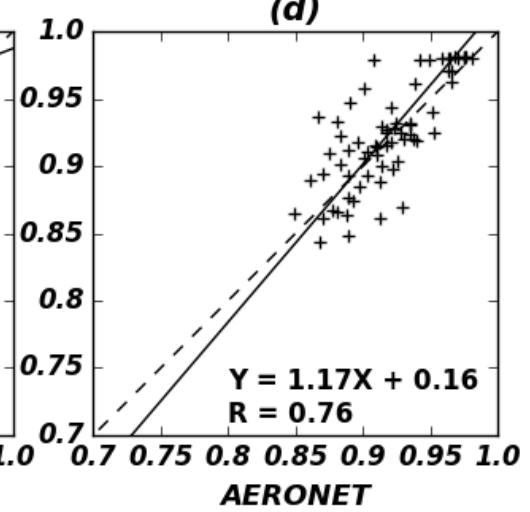

Figure 5. Scatter plots of simulated versus observed SSA at 440 (a, c) and $870 \mathrm{~nm}(\mathrm{~b}, \mathrm{~d})$ from 2008 - 2010. All available AERONET sites were used for (a, b) and filtered AERONET sites were used for (c, d). Reduced major axis regression is shown along with the regression equation and R. Each point indicates monthly averaged SSA when the number of observation was greater than 10 days, and AOD at $440 \mathrm{~nm}$ was greater than 0.4. 
Atmos. Chem. Phys. Discuss., https://doi.org/10.5194/acp-2017-1104

Manuscript under review for journal Atmos. Chem. Phys.

Discussion started: 4 December 2017

(C) Author(s) 2017. CC BY 4.0 License.
Atmospheric

Chemistry

and Physics

Discussions
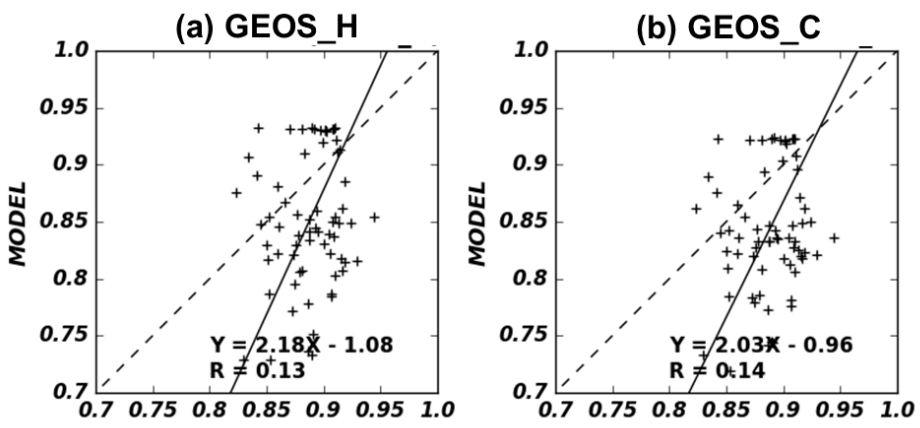

(c) GEOS_BR_E

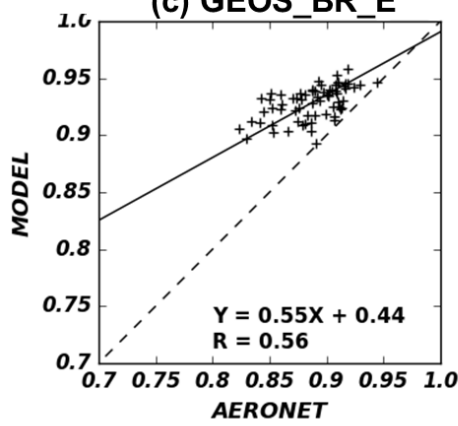

(d) GEOS_DI_E

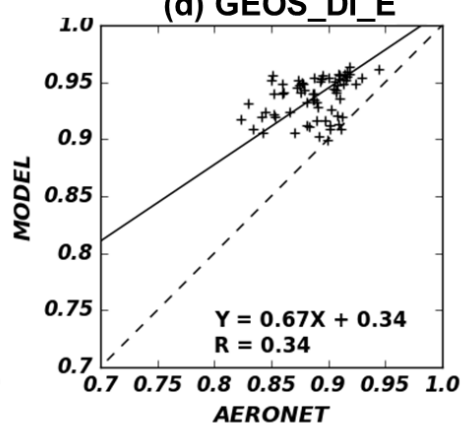

Figure 6. Scatter plots of simulated versus observed SSA at $440 \mathrm{~nm}$ for sensitivity simulations of (a) GEOS_H (Homogeneous internal mixing), (b) GEOS_C (Core-shell internal mixing), (c) GEOS_BR_E (External mixing with brown carbon absorption), and (d) GEOS_DI_E (External mixing with observationally-constrained dust size distribution). 
Atmos. Chem. Phys. Discuss., https://doi.org/10.5194/acp-2017-1104

Manuscript under review for journal Atmos. Chem. Phys.

Discussion started: 4 December 2017

(c) Author(s) 2017. CC BY 4.0 License.
Atmospheric

Chemistry

and Physics

Discussions (a) GEOS_BR_DI_E

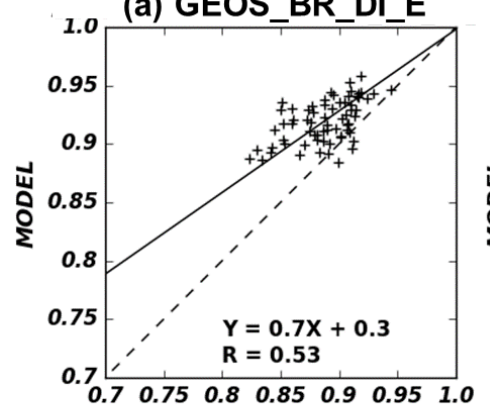

(c) BBR_BR_DI_E

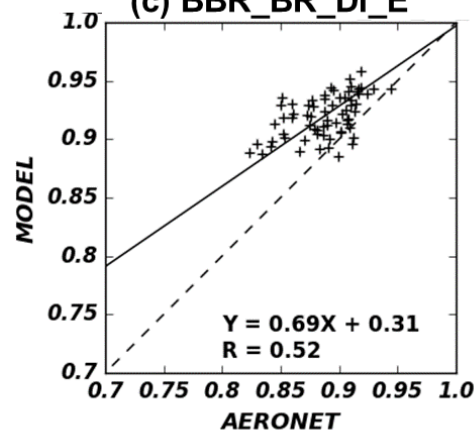

(b) BB BR DI E
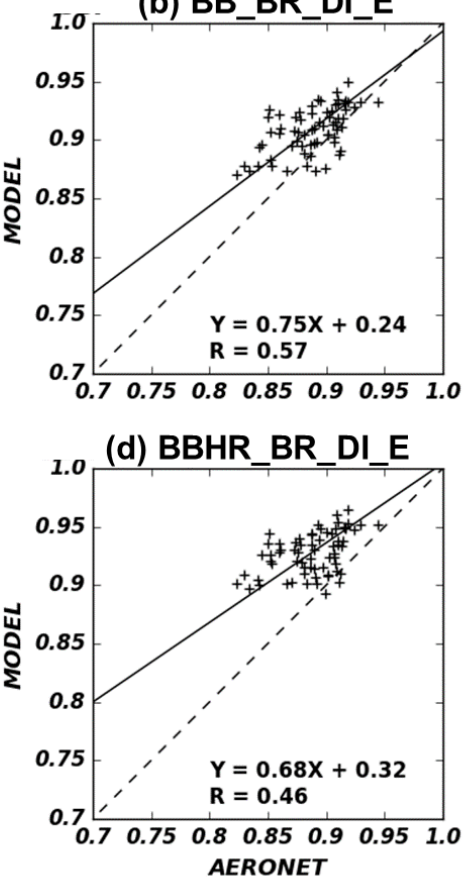

Figure 7. Scatter plots of simulated versus observed SSA at $440 \mathrm{~nm}$ for sensitivity simulations of (a) GEOS_BR_DI_E, (b) BB_BR_DI_E, (c) BBR_BR_DI_E, and (d) BBHR_BR_DI_E. GEOS, BB, BBR, and BBHR represent different BC input parameters as described in Table 3 . BR_DI_E indicates the external mixing assumption with brown carbon absorption and observationally-constrained dust size distribution. 
Atmos. Chem. Phys. Discuss., https://doi.org/10.5194/acp-2017-1104

Manuscript under review for journal Atmos. Chem. Phys.

Discussion started: 4 December 2017

(c) Author(s) 2017. CC BY 4.0 License.
Atmospheric

Chemistry

and Physics

Discussions (a) GEOS_BR_DI_E

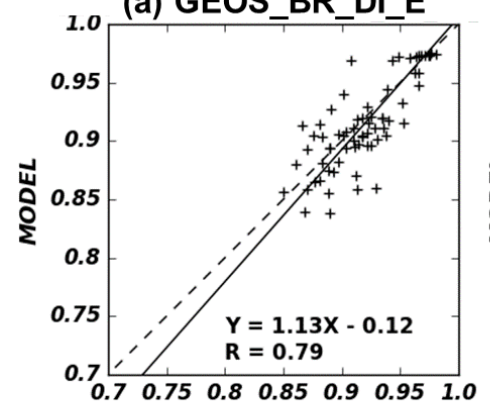

(c) BBR_BR_DI_E

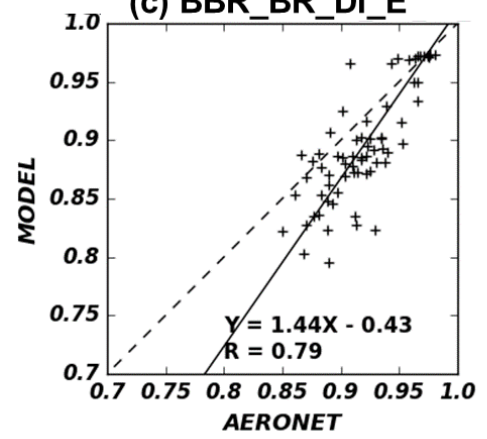

(b) BB BR DI E
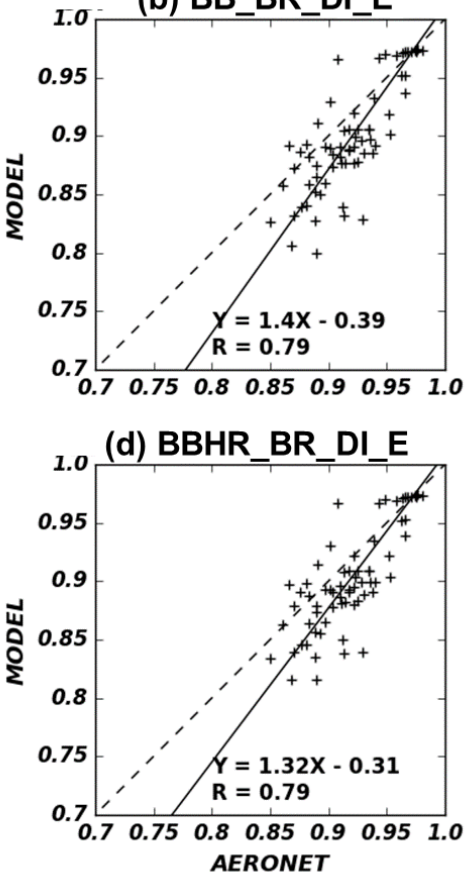

Figure 8. Scatter plots of simulated versus observed SSA at $870 \mathrm{~nm}$ for sensitivity simulations of (a) GEOS_BR_DI_E, (b) BB_BR_DI_E, (c) BBR_BR_DI_E, and (d) BBHR_BR_DI_E. GEOS, BB, BBR, and BBHR represent different BC input parameters as described in Table 3. BR_DI_E indicates the external mixing assumption with brown carbon absorption and observationally-constrained dust size distribution. 
Atmos. Chem. Phys. Discuss., https://doi.org/10.5194/acp-2017-1104

Manuscript under review for journal Atmos. Chem. Phys.

Discussion started: 4 December 2017

(c) Author(s) 2017. CC BY 4.0 License.
Atmospheric

Chemistry

and Physics

Discussions

(c) (1)

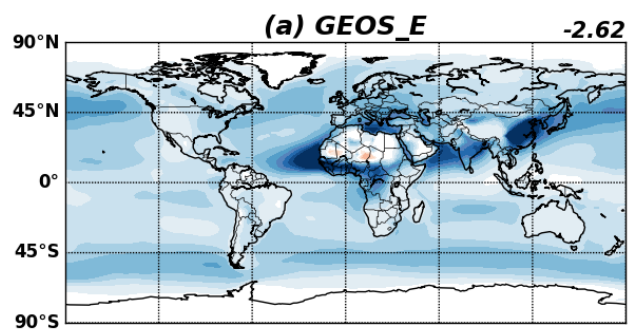

Unit : $\mathbf{W} \mathbf{m}^{-2}$
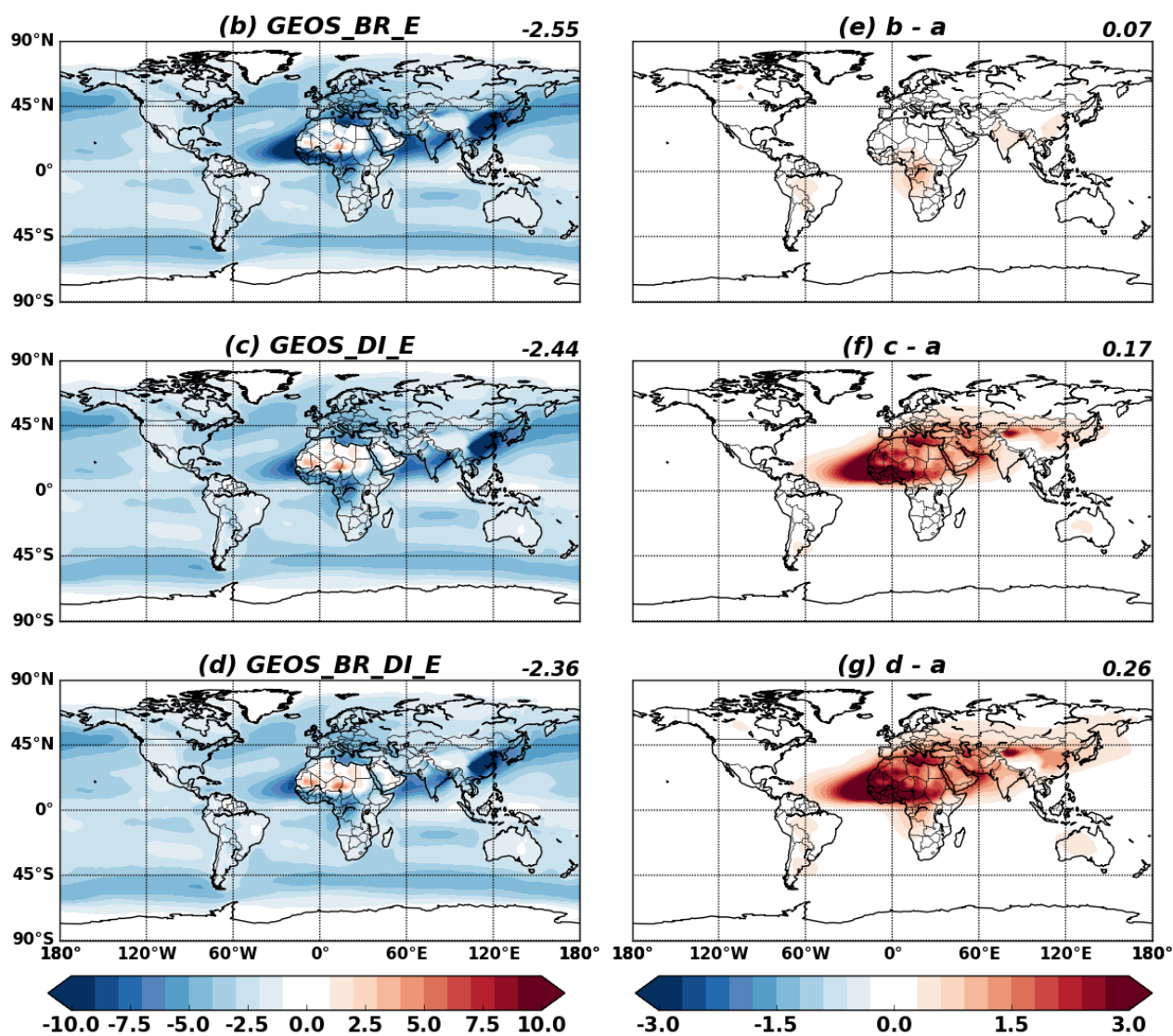

Figure 9. Calculated DREs at the top of the atmosphere. Left panels are the DREs of the (a) GEOS_E, (b) GEOS_BR_E, (c) GEOS_DI_E, and (d) GEOS_BR_DI_E cases. The changes compared with the GEOS_E case are shown in right column. 


\section{References}

Alexander, B., Park, R. J., Jacob, D. J., Li, Q., Yantosca, R. M., Savarino, J., Lee, C., and Thiemens, M.: Sulfate formation in sea- salt aerosols: Constraints from oxygen isotopes, Journal of Geophysical Research: Atmospheres (1984-2012), 110, 2005.

5 Alexander, D. T. L., Crozier, P. A., and Anderson, J. R.: Brown carbon spheres in East Asian outflow and their optical properties, Science, 321, 833, 2008.

Bey, I., Jacob, D. J., Yantosca, R. M., and Logan, J. A.: Global modeling of tropospheric chemistry with assimilated meteorology- Model description and evaluation, Journal of Geophysical Research, 106, 073-023,095, 2001.

10 Bond, T. C. and Bergstrom, R. W.: Light absorption by carbonaceous particles: An investigative review, Aerosol Science and Technology, 40, 27-67, 2006.

Bond, T. C., Doherty, S. J., Fahey, D. W., Forster, P. M., Berntsen, T., DeAngelo, B. J., Flanner, M. G., Ghan, S., Kärcher, B., Koch, D., Kinne, S., Kondo, Y., Quinn, P. K., Sarofim, M. C., Schultz, M. G., Schulz, M., Venkataraman, C., Zhang, H., Zhang, S., Bellouin, N.,

15 Guttikunda, S. K., Hopke, P. K., Jacobson, M. Z., Kaiser, J. W., Klimont, Z., Lohmann, U., Schwarz, J. P., Shindell, D., Storelvmo, T., Warren, S. G., and Zender, C. S.: Bounding the role of black carbon in the climate system: A scientific assessment, Journal of Geophysical Research, doi: 10.1002/jgrd.50171, 2013. n/a-n/a, 2013.

Bond, T. C., Habib, G., and Bergstrom, R. W.: Limitations in the enhancement of visible light

20 absorption due to mixing state, Journal of Geophysical Research: Atmospheres (1984-2012), $111,2006$.

Cappa, C. D., Onasch, T. B., Massoli, P., Worsnop, D. R., Bates, T. S., Cross, E. S., Davidovits, P., Hakala, J., Hayden, K. L., and Jobson, B. T.: Radiative absorption enhancements due to the mixing state of atmospheric black carbon, Science, 337, 1078-1081, 2012.

Chin, M., Diehl, T., Dubovik, O., Eck, T., Holben, B., Sinyuk, A., and Streets, D.: Light absorption by pollution, dust, and biomass burning aerosols: a global model study and evaluation with AERONET measurements, Annales Geophysicae, 27, 3439-3464, 2009.

Chin, M., Ginoux, P., Kinne, S., Torres, O., Holben, B. N., Duncan, B. N., Martin, R. V.,

30 Logan, J. A., Higurashi, A., and Nakajima, T.: Tropospheric Aerosol Optical Thickness from the GOCART Model and Comparisons with Satellite and Sun Photometer Measurements, Journal of Atmospheric Sciences, 59, 461-483, 2002.

Chung, C., Kim, S. W., Lee, M., Yoon, S. C., and Lee, S.: Carbonaceous aerosol AAE inferred from in-situ aerosol measurements at the Gosan ABC super site, and the implications for brown carbon aerosol, Atmospheric Chemistry and Physics, 12, 6173-6184, 2012. 

Giordano, L., Hirtl, M., Honzak, L., Jiménez-Guerrero, P., Knote, C., Langer, M., Makar, P. A., Pirovano, G., Pérez, J. L., San José, R., Syrakov, D., Tuccella, P., Werhahn, J., Wolke, R., Žabkar, R., Zhang, J., and Galmarini, S.: Uncertainties of simulated aerosol optical properties 5 induced by assumptions on aerosol physical and chemical properties: An AQMEII-2 perspective, Atmospheric Environment, 115, 541-552, 2015.

Curier, R., Kranenburg, R., Segers, A., Timmermans, R., and Schaap, M.: Synergistic use of OMI NO 2 tropospheric columns and LOTOS-EUROS to evaluate the NO x emission trends across Europe, Remote Sensing of Environment, 149, 58-69, 2014.

10 Dai, T., Shi, G., and Nakajima, T.: Analysis and evaluation of the global aerosol optical properties simulated by an online aerosol-coupled non-hydrostatic icosahedral atmospheric model, Advances in Atmospheric Sciences, 32, 743-758, 2015.

Drury, E., Jacob, D. J., Spurr, R. J., Wang, J., Shinozuka, Y., Anderson, B. E., Clarke, A. D., Dibb, J., McNaughton, C., and Weber, R.: Synthesis of satellite (MODIS), aircraft (ICARTT),

15 and surface (IMPROVE, EPA- AQS, AERONET) aerosol observations over eastern North America to improve MODIS aerosol retrievals and constrain surface aerosol concentrations and sources, Journal of Geophysical Research: Atmospheres (1984-2012), 115, 2010.

Dubovik, O., Holben, B., Eck, T. F., Smirnov, A., Kaufman, Y. J., King, M. D., Tanré, D., and Slutsker, I.: Variability of absorption and optical properties of key aerosol types observed in worldwide locations, Journal of the atmospheric sciences, 59, 590-608, 2002.

Fairlie, T. D., Jacob, D. J., and Park, R. J.: The impact of transpacific transport of mineral dust in the United States, Atmospheric Environment, 41, 1251-1266, 2007.

Farias, T. L., Köylü, Ü. Ö., and Carvalho, M. d. G.: Range of validity of the RayleighDebye-Gans theory for optics of fractal aggregates, Applied Optics, 35, 6560-6567, 1996.

25 Feng, Y., Ramanathan, V., and Kotamarthi, V.: Brown carbon: a significant atmospheric absorber of solar radiation?, Atmospheric Chemistry and Physics, 13, 8607-8621, 2013.

Fountoukis, C. and Nenes, A.: ISORROPIA II: a computationally efficient thermodynamic equilibrium model for $\mathrm{K}+-\mathrm{Ca} 2+-\mathrm{Mg} 2+-\mathrm{NH} 4+-\mathrm{Na}+-\mathrm{SO} 42--\mathrm{NO} 3-\mathrm{Cl}-\mathrm{H} 2 \mathrm{O}$ aerosols, Atmospheric Chemistry and Physics Discussions, 7, 1893-1939, 2007.

30 Giglio, L., Randerson, J. T., and Werf, G. R.: Analysis of daily, monthly, and annual burned area using the fourth- generation global fire emissions database (GFED4), Journal of Geophysical Research: Biogeosciences, 118, 317-328, 2013.

Ginoux, P., Chin, M., Tegen, I., Prospero, J. M., Holben, B., Dubovik, O., and Lin, S. J.: Sources and distributions of dust aerosols simulated with the GOCART model, Journal of Geophysical Research: Atmospheres (1984-2012), 106, 20255-20273, 2001. 
Granier, C., Bessagnet, B., Bond, T., D’Angiola, A., Denier van der Gon, H., Frost, G. J., Heil, A., Kaiser, J. W., Kinne, S., and Klimont, Z.: Evolution of anthropogenic and biomass burning emissions of air pollutants at global and regional scales during the 1980-2010 period, Climatic Change, 109, 163-190, 2011.

5 Gu, Y. and Liao, H.: Summertime nitrate aerosol in the upper troposphere and lower stratosphere over the Tibetan Plateau and the South Asian summer monsoon region, Atmospheric Chemistry and Physics Discussions, 15, 32049-32099, 2015.

Guenther, A., Jiang, X., Heald, C., Sakulyanontvittaya, T., Duhl, T., Emmons, L., and Wang, X.: The Model of Emissions of Gases and Aerosols from Nature version 2.1 (MEGAN2. 1):

10 an extended and updated framework for modeling biogenic emissions, Geoscientific Model Development, 5, 1471-1492, 2012.

Heald, C., Collett Jr, J., Lee, T., Benedict, K., Schwandner, F., Li, Y., Clarisse, L., Hurtmans, D., Van Damme, M., and Clerbaux, C.: Atmospheric ammonia and particulate inorganic nitrogen over the United States, Atmospheric Chemistry and Physics Discussions, 12, 1945519498, 2012.

Heald, C., Ridley, D., Kroll, J., Barrett, S., Cady-Pereira, K., Alvarado, M., and Holmes, C.: Contrasting the direct radiative effect and direct radiative forcing of aerosols, Atmospheric Chemistry and Physics, 14, 5513-5527, 2014.

Hess, M., Koepke, P., and Schult, I.: Optical properties of aerosols and clouds: The software package OPAC, Bulletin of the American meteorological society, 79, 831-844, 1998.

Hirsch, R. and Gilroy, E.: Methods of Fitting a Straight Line to Data: Examples in Water Resources, Water Resources Bulletin, 20, 1984.

Iacono, M. J., Delamere, J. S., Mlawer, E. J., Shephard, M. W., Clough, S. A., and Collins, W. D.: Radiative forcing by long- lived greenhouse gases: Calculations with the AER radiative transfer models, Journal of Geophysical Research: Atmospheres (1984-2012), 113, 2008.

Jaeglé, L., Quinn, P., Bates, T., Alexander, B., and Lin, J.-T.: Global distribution of sea salt aerosols: new constraints from in situ and remote sensing observations, Atmospheric Chemistry and Physics, 11, 3137-3157, 2011.

Janssens-Maenhout, G., Crippa, M., Guizzardi, D., Dentener, F., Muntean, M., Pouliot, G.,

30 Keating, T., Zhang, Q., Kurokawa, J., and Wankmüller, R.: HTAP_v2. 2: a mosaic of regional and global emission grid maps for 2008 and 2010 to study hemispheric transport of air pollution, Atmospheric Chemistry and Physics, 15, 11411-11432, 2015.

Jethva, H., Torres, O., and Ahn, C.: Global assessment of OMI aerosol single- scattering albedo using ground- based AERONET inversion, Journal of Geophysical Research: 
Jimenez, J., Canagaratna, M., Donahue, N., Prevot, A., Zhang, Q., Kroll, J., DeCarlo, P., Allan, J., Coe, H., and Ng, N.: Evolution of organic aerosols in the atmosphere, Science, 326, $1525,2009$.

Jo, D., Park, R., Kim, M., and Spracklen, D.: Effects of chemical aging on global secondary organic aerosol using the volatility basis set approach, Atmospheric Environment, 81, 230244, 2013.

Jo, D. S., Park, R. J., Lee, S., Kim, S. W., and Zhang, X.: A global simulation of brown carbon: implications for photochemistry and direct radiative effect, Atmospheric Chemistry and Physics, 16, 3413-3432, 2016.

10 Khatri, P., Takamura, T., Shimizu, A., and Sugimoto, N.: Observation of low single scattering albedo of aerosols in the downwind of the East Asian desert and urban areas during the inflow of dust aerosols, Journal of Geophysical Research: Atmospheres, 119, 787-802, 2014.

Kirchstetter, T. and Thatcher, T.: Contribution of organic carbon to wood smoke particulate matter absorption of solar radiation, Atmospheric Chemistry and Physics, 12, 6067-6072, 2012.

Koch, D., Schulz, M., Kinne, S., McNaughton, C., Spackman, J., Balkanski, Y., Bauer, S., Berntsen, T., Bond, T. C., and Boucher, O.: Evaluation of black carbon estimations in global aerosol models, Atmospheric Chemistry and Physics, 9, 9001-9026, 2009.

Kok, J. F.: A scaling theory for the size distribution of emitted dust aerosols suggests climate

20 models underestimate the size of the global dust cycle, Proceedings of the National Academy of Sciences, 108, 1016-1021, 2011.

Kok, J. F., Ridley, D. A., Zhou, Q., Miller, R. L., Zhao, C., Heald, C. L., Ward, D. S., Albani, S., and Haustein, K.: Smaller desert dust cooling effect estimated from analysis of dust size and abundance, Nature Geoscience, 2017. 2017.

25 Laskin, A., Laskin, J., and Nizkorodov, S. A.: Chemistry of Atmospheric Brown Carbon, Chemical reviews, 115, 4335-4382, 2015.

Lin, G., Penner, J. E., Flanner, M. G., Sillman, S., Xu, L., and Zhou, C.: Radiative forcing of organic aerosol in the atmosphere and on snow: Effects of SOA and brown carbon, Journal of Geophysical Research: Atmospheres, 119, 7453-7476, 2014.

30 Loeb, N. G. and Su, W.: Direct aerosol radiative forcing uncertainty based on a radiative perturbation analysis, Journal of Climate, 23, 5288-5293, 2010.

Liu, S., Aiken, A. C., Gorkowski, K., Dubey, M. K., Cappa, C. D., Williams, L. R., Herndon, S. C., Massoli, P., Fortner, E. C., and Chhabra, P. S.: Enhanced light absorption by mixed source black and brown carbon particles in UK winter, Nature communications, 6, 2015. 
Mahowald, N., Albani, S., Kok, J. F., Engelstaeder, S., Scanza, R., Ward, D. S., and Flanner, M. G.: The size distribution of desert dust aerosols and its impact on the Earth system, Aeolian Research, 15, 53-71, 2014.

Malm, W. C., Sisler, J. F., Huffman, D., Eldred, R. A., and Cahill, T. A.: Spatial and seasonal

Martin, R. V., Jacob, D. J., Yantosca, R. M., Chin, M., and Ginoux, P.: Global and regional decreases in tropospheric oxidants from photochemical effects of aerosols, Journal of Geophysical Research, 108, 4097, 2003.

10 McComiskey, A., Schwartz, S. E., Schmid, B., Guan, H., Lewis, E. R., Ricchiazzi, P., and Ogren, J. A.: Direct aerosol forcing: Calculation from observables and sensitivities to inputs, Journal of Geophysical Research: Atmospheres, 113, 2008.

Mishchenko, M. I.: Electromagnetic scattering by nonspherical particles: A tutorial review, Journal of Quantitative Spectroscopy and Radiative Transfer, 110, 808-832, 2009.

15 Mishchenko, M. I., Travis, L. D., and Lacis, A. A.: Scattering, absorption, and emission of light by small particles, Cambridge university press, 2002.

Myhre, G., Berglen, T., Johnsrud, M., Hoyle, C., Berntsen, T., Christopher, S., Fahey, D., Isaksen, I., Jones, T., and Kahn, R.: Modelled radiative forcing of the direct aerosol effect with multi-observation evaluation, Atmospheric Chemistry and Physics, 9, 1365-1392, 2009.

20 Myhre, G., D. Shindell, F.-M. Bréon, W. Collins, J. Fuglestvedt, J. Huang, D. Koch, J.-F. Lamarque, D. Lee, B. Mendoza, T. Nakajima, A. Robock, G. Stephens, Takemura, T., and Zhang, H.: Anthropogenic and Natural Radiative Forcing. In: Climate Change 2013: The Physical Science Basis. Contribution of Working Group I to the Fifth Assessment Report of the Intergovernmental Panel on Climate Change, Climate change, 2013a. 659-740, $2013 \mathrm{a}$.

25 Myhre, G., Samset, B., Schulz, M., Balkanski, Y., Bauer, S., Berntsen, T., Bian, H., Bellouin, N., Chin, M., and Diehl, T.: Radiative forcing of the direct aerosol effect from AeroCom Phase II simulations, Atmospheric Chemistry and Physics, 13, 1853-1877, 2013b.

Park, R. J., Jacob, D. J., Chin, M., and Martin, R. V.: Sources of carbonaceous aerosols over the United States and implications for natural visibility, Journal of Geophysical Research, $108,4355,2003$.

Park, R. J., Jacob, D. J., Field, B. D., Yantosca, R. M., and Chin, M.: Natural and transboundary pollution influences on sulfate-nitrate-ammonium aerosols in the United States: Implications for policy, Journal of Geophysical Research, 109, D15204, 2004.

Pye, H., Chan, A., Barkley, M., and Seinfeld, J.: Global modeling of organic aerosol: the 
importance of reactive nitrogen (NO_x and NO_3), Atmospheric Chemistry and Physics, 10, 11261-11276, 2010.

Pye, H. O. T., Liao, H., Wu, S., Mickley, L. J., Jacob, D. J., Henze, D. J., and Seinfeld, J. H.: Effect of changes in climate and emissions on future sulfate-nitrate-ammonium aerosol levels in the United States, Journal of Geophysical Research, 114, 2009.

Rienecker, M. M., Suarez, M. J., Gelaro, R., Todling, R., Bacmeister, J., Liu, E., Bosilovich, M. G., Schubert, S. D., Takacs, L., and Kim, G.-K.: MERRA: NASA's modern-era retrospective analysis for research and applications, Journal of Climate, 24, 3624-3648, 2011.

Schiferl, L. D., Heald, C. L., Nowak, J. B., Holloway, J. S., Neuman, J. A., Bahreini, R.,

10 Pollack, I. B., Ryerson, T. B., Wiedinmyer, C., and Murphy, J. G.: An investigation of ammonia and inorganic particulate matter in California during the CalNex campaign, Journal of Geophysical Research: Atmospheres, 119, 1883-1902, 2014.

Schultz, M., Backman, L., Balkanski, Y., Bjoerndalsaeter, S., Brand, R., Burrows, J., Dalsoeren, S., De Vasconcelos, M., Grodtmann, B., and Hauglustaine, D.: REanalysis of the

15 TROpospheric chemical composition over the past 40 years (RETRO)-A long-term global modeling study of tropospheric chemistry, Final Report, Jülich/Hamburg, Germany, 2007. 2007.

Shiraiwa, M., Kondo, Y., Moteki, N., Takegawa, N., Sahu, L., Takami, A., Hatakeyama, S., Yonemura, S., and Blake, D.: Radiative impact of mixing state of black carbon aerosol in

20 Asian outflow, Journal of Geophysical Research: Atmospheres (1984-2012), 113, 2008.

Simon, H., Reff, A., Wells, B., Xing, J., and Frank, N.: Ozone trends across the United States over a period of decreasing NOx and VOC emissions, Environmental science \& technology, 49, 186-195, 2014.

Snider, G., Weagle, C., Martin, R., Van Donkelaar, A., Conrad, K., Cunningham, D., Gordon, 25 C., Zwicker, M., Akoshile, C., and Artaxo, P.: SPARTAN: a global network to evaluate and enhance satellite-based estimates of ground-level particulate matter for global health applications, Atmospheric Measurement Techniques, 8, 505-521, 2015.

Snider, G., Weagle, C. L., Murdymootoo, K. K., Ring, A., Ritchie, Y., Stone, E., Walsh, A., Akoshile, C., Anh, N. X., and Balasubramanian, R.: Variation in global chemical composition

30 of PM 2.5: emerging results from SPARTAN, Atmospheric Chemistry and Physics, 16, 96299653, 2016.

Spracklen, D. V., Jimenez, J. L., Carslaw, K. S., Worsnop, D. R., Evans, M. J., Mann, G. W., Zhang, Q., Canagaratna, M. R., Allan, J., Coe, H., McFiggans, G., Rap, A., and Forster, P.: Aerosol mass spectrometer constraint on the global secondary organic aerosol budget, Atmospheric Chemistry and Physics., 11, 12109-12136, 2011. 
Srivastava, R., Ramachandran, S., Rajesh, T., and Kedia, S.: Aerosol radiative forcing deduced from observations and models over an urban location and sensitivity to single scattering albedo, Atmospheric environment, 45, 6163-6171, 2011.

Stettler, M., Eastham, S., and Barrett, S.: Air quality and public health impacts of UK airports. Part I: Emissions, Atmospheric environment, 45, 5415-5424, 2011.

Stier, P., Seinfeld, J. H., Kinne, S., and Boucher, O.: Aerosol absorption and radiative forcing, Atmospheric Chemistry and Physics, 7, 5237-5261, 2007.

Sinyuk, A., Torres, O., and Dubovik, O.: Combined use of satellite and surface observations to infer the imaginary part of refractive index of Saharan dust, Geophysical Research Letters, 30, 2003.

Tsigaridis, K., Daskalakis, N., Kanakidou, M., Adams, P., Artaxo, P., Bahadur, R., Balkanski, Y., Bauer, S., Bellouin, N., and Benedetti, A.: The AeroCom evaluation and intercomparison of organic aerosol in global models, Atmospheric Chemistry and Physics, 14, 10845-10895, 2014.

15 van Donkelaar, A., Martin, R. V., Brauer, M., and Boys, B. L.: Use of satellite observations for long-term exposure assessment of global concentrations of fine particulate matter, Environmental health perspectives, 123, 135, 2015.

Wang, J. X.: Mapping the Global Dust Storm Records: Review of Dust Data Sources in Supporting Modeling/Climate Study, Current Pollution Reports, 1, 82-94, 2015.

20 Wang, X., Heald, C., Ridley, D., Schwarz, J., Spackman, J., Perring, A., Coe, H., Liu, D., and Clarke, A.: Exploiting simultaneous observational constraints on mass and absorption to estimate the global direct radiative forcing of black carbon and brown carbon, Atmospheric Chemistry and Physics, 14, 10989-11010, 2014.

Wang, Y., Zhang, Q., He, K., Zhang, Q., and Chai, L.: Sulfate-nitrate-ammonium aerosols over China: response to 2000-2015 emission changes of sulfur dioxide, nitrogen oxides, and ammonia, Atmospheric Chemistry and Physics, 13, 2635-2652, 2013.

Yang, M., Howell, S., Zhuang, J., and Huebert, B.: Attribution of aerosol light absorption to black carbon, brown carbon, and dust in China-interpretations of atmospheric measurements during EAST-AIRE, Atmospheric Chemistry and Physics, 9, 2035-2050, 2009.

30 Ye, C., Zhang, N., Gao, H., and Zhou, X.: Photolysis of particulate nitrate as a source of HONO and NOx, Environmental Science \& Technology, 2017. 2017.

Yu, F.: A secondary organic aerosol formation model considering successive oxidation aging and kinetic condensation of organic compounds: global scale implications, Atmospheric Chemistry and Physics, 11, 1083-1099, 2011. 
Atmos. Chem. Phys. Discuss., https://doi.org/10.5194/acp-2017-1104

Manuscript under review for journal Atmos. Chem. Phys.

Discussion started: 4 December 2017

(c) Author(s) 2017. CC BY 4.0 License.

Zender, C. S., Bian, H., and Newman, D.: Mineral Dust Entrainment and Deposition (DEAD) model: Description and 1990s dust climatology, Journal of Geophysical Research:

Atmospheres (1984-2012), 108, 2003.

Zhang, L., Jacob, D., Knipping, E., Kumar, N., Munger, J., Carouge, C., Donkelaar, A. v., 5 Wang, Y., and Chen, D.: Nitrogen deposition to the United States: distribution, sources, and processes, Atmospheric Chemistry and Physics, 12, 4539-4554, 2012.

Zhang, L., Kok, J. F., Henze, D. K., Li, Q., and Zhao, C.: Improving simulations of fine dust surface concentrations over the western United States by optimizing the particle size distribution, Geophysical Research Letters, 40, 3270-3275, 2013.

10 Zhang, Q., Jimenez, J., Canagaratna, M., Allan, J., Coe, H., Ulbrich, I., Alfarra, M., Takami, A., Middlebrook, A., and Sun, Y.: Ubiquity and dominance of oxygenated species in organic aerosols in anthropogenically-influenced Northern Hemisphere midlatitudes, Geophysical Research Letters, 34, L13801, 2007.

Zhu, L., Henze, D., Bash, J., Jeong, G.-R., Cady-Pereira, K., Shephard, M., Luo, M., Paulot,

15 F., and Capps, S.: Global evaluation of ammonia bidirectional exchange and livestock diurnal variation schemes, Atmospheric Chemistry and Physics, 15, 12823-12843, 2015.

Zhu, L., Henze, D., Cady- Pereira, K., Shephard, M., Luo, M., Pinder, R., Bash, J., and Jeong, G. R.: Constraining US ammonia emissions using TES remote sensing observations and the GEOS- Chem adjoint model, Journal of Geophysical Research: Atmospheres, 118, 3355-3368, 2013. 